1

2

3

4

5

6

7

8

9
DR. SARA C. BELL (Orcid ID : 0000-0003-1327-0360)

Article type : Articles

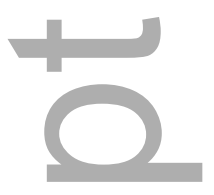

-

Running head: Recovery of rainforest frogs

\title{
Connectivity over a disease risk gradient enables recovery of rainforest frogs
}

Sara C. Bell ${ }^{1,2,3, *}$, Geoffrey W. Heard ${ }^{4,5}$, Lee Berger ${ }^{2}$ and Lee F. Skerratt ${ }^{2}$

${ }^{1}$ College of Public Health, Medical and Veterinary Sciences, James Cook University,

Townsville, Queensland 4811, Australia

${ }^{2}$ One Health Research Group, Melbourne Veterinary School, Faculty of Veterinary and

Agricultural Sciences, University of Melbourne, Werribee, Victoria 3030, Australia

${ }^{3}$ Current address: Australian Institute of Marine Science, PMB 3, Townsville MC, Queensland 4810, Australia

${ }^{4}$ Institute of Land, Water and Society, Charles Sturt University, Albury, New South Wales 2640, Australia

${ }^{5}$ Arthur Rylah Institute for Environmental Research, Victorian Department of Environment, Land, Water and Planning, Heidelberg, Victoria 3084, Australia

*Corresponding author (email: saracbell@gmail.com)

\section{Abstract}

Chytridiomycosis has been a key driver of global frog declines and extinctions, particularly for

high-altitude populations across Australia and the Americas. While recent evidence shows some

This is the author manuscript accepted for publication and has undergone full peer review but has not been through the copyediting, typesetting, pagination and proofreading process, which may lead to differences between this version and the Version of Record. Please cite this article as doi: $\underline{10.1002 / E A P .2152}$ 
species are recovering, the extent of such recoveries and the mechanisms underpinning them remain poorly resolved. We surveyed the historical latitudinal and elevational range of four Australian rainforest frogs that disappeared from upland sites between 1989 and 1994 to establish their contemporary distribution and elevational limits, and investigate factors affecting population recovery. Five rainforest streams were surveyed from mountain-base to summit (30 sites in total), with swabs collected from the target species (Litoria dayi, L. nannotis, L. rheocola and $L$. serrata) to determine their infection status, and dataloggers deployed to measure microclimatic variation across the elevational gradient. Infection probability increased with elevation and canopy cover as it was tightly and inversely correlated with stream-side air temperature. Occupancy patterns suggest varying responses to this disease threat gradient. Two species $-L$. rheocola and L. serrata - were found over their full historical elevational range ( $\geq$ $1000 \mathrm{~m}$ asl), while L. dayi was not detected above $400 \mathrm{~m}$ (formerly known up to $900 \mathrm{~m}$ asl) and L. nannotis was not detected above $800 \mathrm{~m}$ (formerly known up to $1200 \mathrm{~m}$ asl). Site occupancy probability was negatively related to predicted infection prevalence for L. dayi, L. nannotis and L. rheocola, but not L. serrata, which appears to now tolerate high fungal burdens. This study highlights the importance of environmental refuges and connectivity across disease risk gradients for the persistence and natural recovery of frogs susceptible to chytridiomycosis. Likewise, in documenting both interspecific variation in recovery rates and intraspecific differences between sites, this study suggests interactions between disease threats and host selection exist that could be manipulated. For example, translocations may be warranted where connectivity is poor or the increase in disease risk is too steep to allow recolonization, combined with assisted selection or use of founders from populations that have already undergone natural selection.

Keywords: amphibian, connectivity, chytridiomycosis, disease, gradient, infection risk, prevalence, recovery, refuge, simulation, temperature.

\section{Introduction}

The impact of disease epidemics on wildlife populations is strongly influenced by environmental cofactors such as climate and habitat conditions (Colhoun 1973, van Riper et al. 1986, Harvell et al. 2002, Gonzalez-Quevedo et al. 2014). The mechanisms are numerous, and may operate in 
61 isolation, additively or interactively. They include environmental tolerances of the pathogen

62 (Puschendorf et al. 2006, Verant et al. 2012), habitat preferences of vectors or reservoir hosts

63 (Samuel et al. 2011; Brannelly et al. 2018), and environmentally-driven variation in

64 immunocompetence (Flory et al. 2012). Together, these environmental cofactors can result in

65 profound spatial variation in disease risk (Murray et al. 2011), with corresponding variation in selective pressure for resistance (Savage et al. 2015). Variation in disease risk may range from

67 environmental refuges where selection pressure is negligible, through intermediary zones where

68 moderate disease risk allows spatially or temporally patchy occupancy, to complete host extinction in locations where mortality consistently exceeds recruitment (Scheele et al. 2017c).

Population-level impacts of infectious diseases are also mediated by the connectivity of host

72 populations. In theory, host connectivity can have both negative and positive effects. The former

73 derives from host-to-host transmission, and the capacity of migrants to spread infectious

74 pathogens among host populations (Hess 1996, Harding et al. 2012). Impacts of dispersal-

75 mediated transmission can be devastating, particularly during the epizootic phase (Daversa et al.

76 2017). However, connectivity can have significant benefits when hosts are somewhat tolerant of

77 direct pathogen transmission or where host-to-host transmission plays a relatively minimal role

78 in pathogen spread, as may be the case for facultative pathogens with numerous reservoir hosts

79 and/or environmental transmission (Gog et al. 2002, Heard et al. 2015). Here, migration

80 contributes to demographic resilience, by offsetting pathogen-induced mortality (Muths et al.

81 2011, Spitzen-van der Sluijs et al. 2017) or by allowing for population re-establishment

82 following local extinctions (Snall et al. 2008, Jousimo et al. 2014, Heard et al. 2015). Similarly,

83 connectivity can allow for the spread of resistant genotypes, either those that occurred within the

84 gene pool at the time of initial epidemics or those that evolve thereafter, consistent with the

85 Geographic Mosaic Theory of Coevolution (Thompson 1999). For example, Hawaiian

86 honeycreepers have recently recolonised lowland areas from higher elevation refuges following

87 the evolution of resistance to avian malaria, with connectivity across the gradient of disease risk

88 (vector abundance) also likely to have been important in facilitating the evolution of pathogen

89 tolerance (Atkinson et al. 2013). 
Chytridiomycosis in amphibians, caused by the fungal pathogen Batrachochytrium dendrobatidis

92 (hereafter $B d$ ), provides an informative case study of the role of connectivity across

93

94

95

96

97

98

99

100

101

102

103

104

105

106

107

108

109

110

111

112

113

114

115

116

117

118

119

120

121

environmental gradients in determining the persistence and recovery of species afflicted by novel pathogens. Chytridiomycosis has decimated frog populations in the Americas and Australia since the spread of the global panzootic strain late last century (Berger et al. 1998, Skerratt et al. 2007, O'Hanlon et al. 2018, Scheele et al. 2019). In Australia, seven species appear to have been lost entirely, and a further 36 have suffered population declines (Scheele et al. 2017b, Scheele et al. 2019). Rainforest endemics occupying upland sites above $300 \mathrm{~m}$ in elevation in Queensland's Wet Tropics were particularly affected (Berger et al. 1998, Scheele et al. 2017b), with eight species of frogs declining or suffering local extinctions (Ingram and McDonald 1993, Richards et al. 1993). Three species restricted to upland rainforest have not been seen since the early 1990s; the Mountain Mistfrog Litoria nyakalensis, Northern Tinkerfrog Taudactylus rheophilus and Sharp-snouted Dayfrog T. acutirostris (Ingram and McDonald 1993, McDonald 1994, Trenerry et al. 1994). The Armoured Mistfrog (L. lorica), also a high elevation rainforest specialist, was presumed extinct until rediscovered in 2008 within a small refuge of warmer and drier habitat on the western slopes of the Wet Tropics (Puschendorf et al. 2011).

Four species displayed significant declines, but were more broadly distributed latitudinally and elevationally (Figure 1); the Australian Lace-lid Litoria dayi, Waterfall Frog Litoria nannotis, the Common Mistfrog Litoria rheocola and Green-eyed Treefrog Litoria serrata. These species declined precipitously at sites above $400 \mathrm{~m}$ between 1989 and 1994, but persisted in lowlands across their historical range (McDonald and Alford 1999, Richards and Alford 2005). Surveys across the Wet Tropics between 1989 and 1993 frequently documented the last upland sightings of these species (Richards et al. 1993, Trenerry et al. 1994).

One explanation for the elevational pattern of declines throughout the Wet Tropics is that warmer temperatures at lower elevations reduce fungal growth, resulting in reduced pathogenicity and virulence of $B d$ (Berger et al. 2004, Skerratt et al. 2007). Optimal temperatures for $B d$ growth in vitro are generally between $17^{\circ} \mathrm{C}$ and $25^{\circ} \mathrm{C}$ (Piotrowski et al. 2004, Stevenson et al. 2013), and infection and mortality rates decline sharply at temperatures above $26^{\circ} \mathrm{C}$ in animal experiments (Woodhams et al. 2003, Berger et al. 2004, Greenspan et al. 2017). In nature, 
122 infection probability in Australian rainforest frogs is reduced with the increasing proportion of

123 time that animals spend with body temperatures above $25^{\circ} \mathrm{C}$ (Rowley and Alford 2013),

124 matching observations among ecologically-similar high-elevation frogs from central America

125 (Richards-Zawacki 2010). Moreover, as anurans are ectotherms, temperature affects a range of

126 physiological processes relevant to disease susceptibility, including immunity (Rollins-Smith

127 2017) and skin turnover (Meyer et al. 2012). Spatial modelling and analysis of seasonal

128 fluctuations in $B d$ infection suggest that temperature is a key factor mediating disease-induced

129 declines (Murray et al. 2009, Puschendorf et al. 2009, Murray et al. 2011, Murray et al. 2013,

130 Phillott et al. 2013, Sapsford et al. 2013, Grogan et al. 2016).

131

While the threat posed by chytridiomycosis to amphibian biodiversity remains high (Scheele et al. 2019), recovery of amphibians afflicted by chytridiomycosis has been recently documented. Eleven of 43 declined species in Australia have shown some recovery (26\%; Scheele et al. 2017b), while globally signs of recovery have been observed in 60 of 501 declined amphibians (12\%; Scheele et al. 2019). Examples include the recolonization of hundreds of sites in Yosemite National Park, USA, by the Sierra Nevada Yellow-legged Frog Rana sierrae (Knapp et al. 2016), significant re-expansion of the Whistling Treefrog Litoria verreauxii verreauxii in Australia's Southern Highlands (Scheele et al. 2014) and a three- to ten-fold recovery in the abundance of Fleay's Barred Frog Mixophyes fleayi in the rainforests of Australia's eastern seaboard (Newell et al. 2013). In each of these cases, connectivity across disease risk gradients has been an apparent driver of persistence and re-expansion following initial declines.

We sought to characterise the elevational extent of recovery in the four formerly widespread species of frogs from the Australian Wet Tropics (L. dayi, L. nannotis, L. rheocola and L. serrata) and gain insights into the factors affecting persistence and recolonization. Although evidence exists of declined species having recolonized higher elevation sites in the Wet Tropics (McDonald et al. 2005, Woodhams and Alford 2005, Puschendorf et al. 2013, Sapsford et al. 2013), only one study expressly set out to document recolonizations, reporting some higher

151 Wet Tropics (McKnight et al. 2017). Our study represents the most comprehensive attempt to 152 document the recovery of the four focal species across the latitudinal and elevational extent of 
153 their former range. Furthermore, it is the first to assess the ongoing prevalence and intensity of

$154 B d$ infections among these frogs three decades after initial declines, and presents novel insights 155 into the effects of temperature-mediated disease risk on recovery among chytridiomycosis156 impacted amphibians in Australia. Elucidating the role of the various factors involved in the 157 persistence and recovery of $B d$-susceptible anurans has significant ecological, evolutionary and conservation implications (Skerratt et al. 2016).

Methods

\section{Study sites}

Based on availability of species distribution data from upland sites prior to declines, we selected five streams where our target species - L. dayi, L. nannotis, L. rheocola and L. serrata - were known to be, or likely to have been, present prior to declines (Table 1; Figure 1). Streams were roughly latitudinally equidistant across the Wet Tropics bioregion and displayed continuity (and therefore, habitat connectivity) between the uplands and lowlands (Table 1; Figure 1). We refer to these streams as Big Tableland, Mount Lewis, Behana Gorge, Murray-Kirrama and Ethel Creek (in order from northern- to southern-most).

Along each stream, we established sites every $200 \mathrm{~m}$ in elevation with the first lowland site at

$173200 \mathrm{~m}$ above sea level in most cases (Appendix S1: Table S1). Sites were selected using

174 topographic maps and located by GPS. Occasionally, it was not possible to place a survey site at

175 the precise elevation planned due to the presence of topographic features such as large

176 inaccessible waterfalls, gorges and pools. In these cases, sites were repositioned slightly to

177 maximise the chances of locating each species. A $100 \mathrm{~m}$ survey transect was established at each 178 site.

Surveys and Bd sampling

We conducted initial surveys of all sites between May and October 2013 (Austral winter and spring) to maximise chances of finding infected frogs (Berger et al. 2004, Phillott et al. 2013). 
184 Given the extreme difficulty in accessing many of these sites (up to a three-day hike through

185 rugged terrain), most sites received a single survey. However, when a species was not detected at 186 a particular elevation but was recorded at the elevation below, we returned wherever possible to

187 survey an additional elevation between the two sites for three consecutive nights to maximise the 188 chance of locating that species. These additional surveys were undertaken in December 2013 and 189 January 2014.

190

In all cases, surveys were conducted after dark, with each transect walked by two experienced observers and the position and species of every frog recorded. Up to twenty frogs were captured at each site by hand and a skin-swab was taken by rotating a swab (MW100, Medical Wire and Equipment, Bath, UK) over the abdomen, hands, feet and thighs twice to sample $B d$ zoospores (Skerratt et al. 2008). A clean pair of vinyl gloves was worn when handling each frog to prevent disease transmission between animals.

We used quantitative PCR (Real-time TaqMan ${ }^{\circledR}$ assay; Applied Biosystems, Scoresby, VIC, Australia) to diagnose $B d$ infection status as per Boyle et al. (2004) with the addition of bovine serum albumin to reduce the effect of PCR inhibitors (Garland et al. 2010). We used qPCR standards derived from the Wet Tropics $B d$ strain Paluma-Lgenimaculata\#2-2010-MW and considered frogs to be positive for $B d$ infection when 1 zoospore equivalent was present in at least two of the three replicates in order to optimize sensitivity and specificity (Skerratt et al. 2011).

205

We deployed dataloggers (ibutton, model DS1922L; Maxim Integrated, San Jose, California, USA) on the initial visit to each site to record hourly stream-side air temperature, and recovered them during 2014. All ibuttons were coated in Plastidip (Plasti Dip®, Performix®, Plasti Dip International, Bundook, NSW, Australia) to protect them from moisture ingression (Roznik and

212 Alford 2012). On each stream, at each elevation, we secured two replicate air temperature 213 dataloggers in a shaded location at a height of 0.5 to $1.5 \mathrm{~m}$ depending on the availability of 214 suitable vegetation for attachment. All dataloggers were deployed at heights and in habitat where 
215 we would expect to find the focal species, based on our previous experience with these frogs.

216 Due to floods in the wet season, it was not possible to recover some dataloggers. However,

217 where both air temperature loggers were recovered, the mean air temperature was calculated and

218 used in analyses.

219

220 We also collected a hemispherical canopy photograph from the centre of the stream at three

221 points along each $100 \mathrm{~m}$ transect (at approximately $20 \mathrm{~m}, 50 \mathrm{~m}$ and $80 \mathrm{~m}$ ). Percentage canopy

222 cover was calculated using Gap Light Analyzer (v 2.0; Frazer et al. 2000) and mean canopy

223 cover calculated for the site.

224

225

226

227

228

229

Statistical analysis

26

Analyses were undertaken in a Bayesian framework, with models fitted using Markov Chain Monte Carlo (MCMC) sampling in OpenBUGS v. 3.2 .3 (Thomas et al. 2006), called from $R$ v. 3.4.4 (R Core Team 2018). To aid convergence, continuous covariates were centered by subtracting the mean and dividing by two standard deviations. Parameter estimates were derived from 20,000 MCMC samples in all cases (10,000 from each of two chains), after a burn-in of 5,000 samples. Given rapid convergence, chains were not thinned to maximise precision of the posterior distributions (Link and Eaton 2012). We used uninformative priors throughout and compared models with the Deviance Information Criterion (Spiegelhalter et al. 2002) and model selection weights (Burnham and Anderson 2002). All code and data required to reproduce the analysis are provided in a supporting digital archive (Bell et al. 2019).

\section{Microclimatic variation}

We built a linear model of spatio-temporal variation in stream-side air temperature during the survey period, both to allow inference about the drivers of stream-side air temperature and to enable prediction of air temperatures at sites and times for which logger data were missing due to

243 logger failure or loss. We began by restricting recordings to those from midnight, providing a 244 single nightly temperature recording that was centred on the active period of the study species. 245 Model construction commenced by assuming that the five survey streams would differ 
fundamentally in their temperature regime due to latitudinal variation and other factors. As such, the intercept was allowed to vary between streams as a normally-distributed random effect:

$$
\operatorname{temp}_{i}=\alpha_{j[i]}+\varepsilon_{\mathrm{i}}
$$

where $\alpha_{j[i]}$ is the intercept term for temperature recording $i$ at stream $j$ (drawn from a normal distribution with mean of zero and standard deviation [ $\left.\sigma_{a l p h a}\right]$ to be estimated) and $\varepsilon_{i}$ is the residual error term (also drawn from a normal distribution with mean of zero and standard deviation $\left[\sigma_{\text {resid }}\right]$ to be estimated). Effects of season, climate and site were then added in a single global model for the temperature data. The seasonal rise and fall of midnight air temperature was modelled with the aid of a two-parameter cosine function of Julian date. Climatic effects beyond the seasonal trend were modelled using a linear, stream-specific effect of daily maximum temperature recorded at the nearest Australian Bureau of Meteorology (BOM) recording station. Linear effects of elevation and canopy cover on temperature were added given the historical elevational decline of the focal species and the influence of canopy cover on microclimate and $B d$ dynamics observed elsewhere in the Wet Tropics (Skerratt et al. 2007, Roznik et al. 2015). Lastly, due to the sequential nature of the logger data, we accounted for temporal autocorrelation in the recordings by adding a first-order autoregressive term, allowing recording $i$ to be a function of recording $i-1$. The full final model was as follows:

$$
\begin{aligned}
\text { temp }_{i}=\alpha_{j[i]}+ & \beta_{1} \cdot \cos \left(\frac{2 \pi \cdot \text { day }_{i}}{365}\right)+\beta_{2} \cdot \sin \left(\frac{2 \pi \cdot \text { day }_{i}}{365}\right)+\beta_{3_{j[i]}} \cdot \text { maxtemp }_{j[i]}+\beta_{4} . \\
& \text { elevation }_{i}+\beta_{5} \cdot \text { canopy }_{i}+\beta_{6} \cdot \text { temp }_{i-1}+\varepsilon_{i},
\end{aligned}
$$

where $\beta_{1}-\beta_{6}$ are regression coefficients, day $_{i}$ is the Julian date of recording $i$, maxtemp $_{j[i]}$ is the maximum temperature recorded on the day of recording $i$ at the nearest BOM station to stream $j$, elevation $_{i}$ is the site elevation in metres, canopy $_{i}$ is the average canopy cover at the site and temp $p_{i-}$ 1 is the recording on the previous night.

The fitted model was used to predict the midnight air temperature at each site throughout the survey period to allow missing recordings to be imputed. For each of 1000 simulations, air temperature at midnight was estimated at each site on each night using the posterior mean of each model coefficient and the relevant maximum air temperature recorded at the nearest BOM station. The mean prediction across simulations was retained in each case. Model performance 
was also assessed using these predictions, by assessing the correspondence between the predicted and observed temperature for the recordings upon which the model was built.

\section{Infection risk

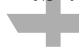

Relationships were explored between stream-side air temperature at midnight and the probability of infection using logistic regression. Linear models of the relationship between stream-side air temperatures and infection load among infected individuals were also pursued, but were ultimately excluded given small sample sizes of infected individuals for some species.

Models were constructed with the assumption that the relationship between temperature and infection probability would be similar among species, but not identical. In this case, the intercept and regression coefficient for the temperature effect for each species were assumed to come from a common distribution with a mean and standard deviation to be estimated from the data. Models of infection probability were constructed as follows:

$$
\begin{gathered}
\operatorname{logit}\left(\gamma_{i}\right)=\alpha_{j[i]}+\beta_{j[i]} \cdot \text { temp }_{i}, \\
\text { infected }_{i} \sim \operatorname{Bernoulli}\left(\gamma_{i}\right),
\end{gathered}
$$

where $\gamma_{i}$ is the probability of infection of frog $i, \alpha_{j[i]}$ is the intercept term for species $j$ to which frog $i$ belongs (drawn from a normal distribution with mean $\mu_{\text {alpha }}$ and standard deviation $\left[\sigma_{\text {alpha }}\right.$ ] to be estimated), $\beta_{j[i]}$ is the effect of midnight air temperature for species $j$ to which frog $i$ belongs (drawn from a normal distribution with mean $\mu_{\text {beta }}$ and standard deviation $\left[\sigma_{\text {beta }}\right]$ to be

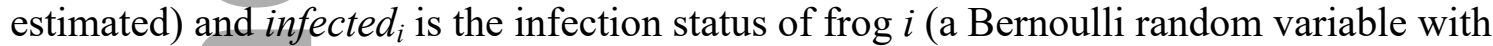
probability $\gamma_{i}$ ). As lagged temperature variables have proven superior predictors of $B d$ infection probability in our study region (Murray et al. 2013, Phillott et al. 2013), we fitted five separate models to the infection data, with midnight air temperature represented as either that on the night of capture or the mean over the preceding 7, 14, 21 and 28 nights.

We used the top-ranked models to produce predictions of $B d$ infection prevalence at each site across the survey period to enable assessment of relationships between infection risk and site occupancy (following Heard et al. 2015). For each site, predictions were constructed by simulating the swabbing of 30 individuals of each species during each month of the survey 
period (May 2013 to January 2014, with sampling assumed to occur on the $15^{\text {th }}$ day of each month). The probability of infection for each frog in each simulation was estimated using the coefficients of the top-ranked infection model, with the relevant midnight air temperature derived either from logger data or predictions when logger data were lacking. We ran 10,000 simulations for each species at each site in each month, each time using a random draw from the joint posterior distribution of the parameters of the relevant infection model. For each species in each simulation, we calculated the prevalence of infections among the 270 frogs sampled across the season ( 30 frogs per month for nine months), by summing the estimated probabilities of infection for each frog and dividing by the number sampled (Hosmer et al. 2013). We transformed these values to the logit scale, and retained the mean and standard deviation across simulations for each species at each site.

\section{Site occupancy versus infection risk}

Relationships between the probability of site occupancy and predicted infection prevalence were assessed using logistic regression. We began by using the repeat surveys at five sites to assess detection probabilities for each species. They were very high in each case, ranging from 0.85 (for L. nannotis) to 1 (for both $L$. dayi and L. rheocola). As such, we treated detection or nondetection data at each site as a reliable indicator of species presence or absence during the survey period.

We fitted two models to the occupancy data for each species: the first being a null model (intercept only) and the second including an effect of predicted infection prevalence on the probability of occupancy. Uncertainty in predicted $B d$ prevalence was propagated by allowing the MCMC algorithm to sample this parameter from a normal distribution defined by the siteand species-specific mean and standard deviation estimated above (on the logit scale). For each species, this model had the form:

$$
\begin{gathered}
\operatorname{logit}\left(\psi_{i}\right)=\alpha+\beta_{1} \cdot \operatorname{prev}_{i}, \\
\operatorname{occupied}_{i} \sim \operatorname{Bernoulli}_{\left(\psi_{i}\right)},
\end{gathered}
$$

where $\psi_{i}$ is the probability of occupancy of site $i, \alpha$ is the intercept term, $\beta_{1}$ is the effect of predicted $B d$ prevalence at site $i\left(\right.$ prev $\left._{i}\right)$ and occupied $_{i}$ is the occupancy status of site $i$ (a 
338 Bernoulli random variable with probability $\psi_{i}$ ). For the purposes of model fitting, only sites along streams at which a given species was detected at least once were included in the dataset for that species.

\section{Results}

\section{General patterns}

At least one of the four focal species was detected at each of the 30 survey sites, but occurrence patterns varied considerably among species (Figure 2). Litoria dayi was detected at just five sites, none of which were above 400 m elevation. It was absent from Big Tableland and Ethel Creek, despite being recorded historically at both locations. Litoria nannotis was widespread, being present at 18 sites in total, although it was absent from Big Tableland (present historically) and detected at only two sites at Mount Lewis. No detections of this species were made above $800 \mathrm{~m}$. Litoria rheocola was detected at 14 sites, including one record at $1000 \mathrm{~m}$ at Mount Lewis. However, most sites at which this species was detected were below $600 \mathrm{~m}$ elevation, and it was not detected at any of the five sites at Ethel Creek (although this accords with historical records). Litoria serrata was widespread and abundant, occurring in all regions and across the entire elevational range. Incidence of this species increased with elevation, in contrast to the other three species. Due to the paucity of pre-decline abundance data, we did not attempt to compare present day with historical abundance.

Skin swabs were taken from 11 L. dayi, 106 L. nannotis, 83 L. rheocola and 147 L. serrata, with observed $B d$ infection prevalence of $18 \%, 35 \%, 28 \%$ and $47 \%$ respectively (Figure 3 ). Infection loads were low for L. dayi and L. nannotis (always $<650$ zoospore equivalents), whereas heavy infections of $>10,000$ zoospore equivalents were detected in both $L$. rheocola and $L$. serrata (Figure 3). Five L. serrata had infections of this intensity or greater, and this species had a high average infection load of 1,961 zoospore equivalents.

\section{Microclimatic variation}


We retrieved 146,793 recordings of stream-side air temperature from the data loggers deployed during this study $($ Big Tableland $=19,353$, Mount Lewis $=43,794$, Behana Gorge = 23,308, Murray-Kirrama $=28,180$, Ethel Creek $=32,104$ ). Recordings were obtained from 23 of the 30 survey sites, covering elevations from $130 \mathrm{~m}$ to $1200 \mathrm{~m}$. Figure 4 shows patterns in the average monthly stream-side air temperature recorded at midnight for sites between $200 \mathrm{~m}$ and $1200 \mathrm{~m}$ in elevation. Average monthly midnight temperatures invariably peaked in January and reached their minimum in August, and consistently declined with increasing elevation. Averaging across streams, mean monthly midnight air temperature ranged from $18.9-24.6^{\circ} \mathrm{C}$ at $200 \mathrm{~m}$, dropping to $16.9-22.9^{\circ} \mathrm{C}$ at $400 \mathrm{~m}, 15.6-21.4^{\circ} \mathrm{C}$ at $600 \mathrm{~m}, 14.4-20.9^{\circ} \mathrm{C}$ at $800 \mathrm{~m}, 13.1-19.7^{\circ} \mathrm{C}$ at 1000 $\mathrm{m}$ and $12.4-18.8^{\circ} \mathrm{C}$ at $1200 \mathrm{~m}$ (Figure 4$)$.

Our linear model of stream-side air temperature at midnight (Table 2), derived from 6099 recordings, fitted the data extremely well $\left(\mathrm{R}^{2}=0.90, \mathrm{RMSE}=0.97^{\circ} \mathrm{C}\right)$. Microclimate of the northern most stream (Big Tableland) was warmer on average than all others (model intercept for Big Tableland $=7.138$, all others $<7$ ); however, microclimates of the remaining streams did not follow a cooling trend with increasing latitude (Table 2). As expected, the effect of maximum daily air temperature recorded at the nearest weather station also varied between streams (and was $>0$ in all cases; Table 2) and stream-side air temperature was strongly positively correlated from night-to-night (autoregressive term $=0.657,95 \% \mathrm{CI}=0.641,0.674$ ).

At the site level, midnight air temperature declined sharply with increasing elevation, and to a lesser degree with increasing canopy cover (Table 2). For illustrative purposes, Figure 5 displays predictions of the mean midnight temperature during August across the elevational and canopy gradient observed at our study sites (with model intercept set to zero, representing an 'average' site). The mean midnight temperature was predicted to be $5.11^{\circ} \mathrm{C}$ cooler at $1200 \mathrm{~m}$ than at $200 \mathrm{~m}$ (on average across the canopy gradient), with an average decline of $1.02^{\circ} \mathrm{C}$ for every $200 \mathrm{~m}$ increase in elevation (Figure 5). Corresponding figures for canopy cover are an average drop of $2.11^{\circ} \mathrm{C}$ between the minimum and maximum canopy covers $(45 \% \& 95 \%)$, with an average decline of $0.42^{\circ} \mathrm{C}$ for every $10 \%$ increase in canopy cover (Figure 5).

\section{Infection risk}

This article is protected by copyright. All rights reserved 
401 The probability of infection decreased sharply as midnight air temperature increased for all four 402 species (Figure 6). This was true for all permutations of midnight air temperature assessed (that 403 on the night of capture, plus lagged measures); however, the average midnight temperature over the preceding 28 nights proved to be the superior predictor of infection probability for all four species (Tables 3). The effect was strongest for $L$. dayi and weakest for $L$. rheocola based on posterior mean values, although the 95\% CIs overlapped extensively among species (Table 4).

Infection probability was predicted to increase in a sigmoidal fashion with increasing elevation and canopy cover for all species, given the negative effects of these two variables on stream-side air temperature. Figure 7 shows this relationship for each species, based on the temperature predictions displayed in Figure 5 for the month of August. Across species, the chance of infection at $200 \mathrm{~m}$ elevation and $45 \%$ canopy cover was predicted to average $9 \%$, being highest for $L$. nannotis (10\%) and lowest for L. serrata $(7 \%)$. The chance of infection was predicted to climb to $94 \%$ on average across species at $1200 \mathrm{~m}$ elevation and $95 \%$ canopy cover, with a minimum of $91 \%$ for L. rheocola and maximum of $96 \%$ for L. nannotis and L. serrata.

\section{Site occupancy versus infection risk}

Of the four focal species, there was evidence of a negative relationship between site occupancy and predicted infection prevalence for $L$. dayi and $L$. rheocola; models including effects of $B d$ prevalence on occupancy rate were superior for these species (Table 5), and $95 \%$ credible intervals for the effect of infection prevalence on the probability of occupancy were $<0$ in each case (Table 6). Sites at which L. dayi was detected displayed a predicted infection prevalence across the study period of $\leq 0.32$, with the equivalent figure for $L$. rheocola being $\leq 0.60$ (Figure 8). The null model was superior for L. nannotis (Table 5) and the effect of predicted $B d$ prevalence on the probability of occupancy was $\sim 0$ (Table 6 ). In contrast to all other species, the incidence of $L$. serrata among sites increased with increasing predicted infection prevalence (Figure 8), and the probability of site occupancy for this species was positively related to infection risk, with a $95 \% \mathrm{CI}>0$ (Table 6). 
This is the first systematic study of the current distribution of rainforest frogs in the Australian Wet Tropics following catastrophic $B d$-related upland population declines and disappearances more than two decades ago. We surveyed sites across both an elevational and latitudinal gradient, and suggest that observed upland recolonizations have been supported by connectivity across a gradient of disease risk that enabled persistence in lowland refuges and gradual adaption between the host and pathogen.

One species appears to have largely recovered (Litoria serrata) and a further two appear to have made partial recoveries (L. nannotis and L. rheocola). Litoria serrata was detected across its full elevational range, was abundant at numerous sites, and persists with high infection prevalence and intensity. Litoria nannotis and L. rheocola were detected at, or close to, their historical elevational range, and persist with high infection prevalence (and intensity in the case of L. rheocola). However, evidence of continued constraints on recovery by chytridiomycosis was found for L. rheocola; despite being found across its full historical elevational range, a negative relationship between site occupancy probability and predicted $B d$ prevalence was apparent for this species (Table 6), corresponding to lower rate of occupancy in cool, shaded sites at higher elevations. Our final target species - L. dayi - appears to have made little or no recovery from initial epizootics, being restricted to warmer, lowland refuges $(\leq 400 \mathrm{~m})$ at which infection

We also found evidence of response variability to chytridiomycosis within species. For example, L. rheocola was present at $600 \mathrm{~m}$ at Big Tableland and $1000 \mathrm{~m}$ at Mt Lewis (our two most northern transects) but was absent above $500 \mathrm{~m}$ at Behana Gorge and $400 \mathrm{~m}$ at Murray-Kirrama, 456 at the southernmost extent of its range. Conversely, L. nannotis was entirely absent from Big 457 Tableland where it occurred historically and at elevations above $500 \mathrm{~m}$ at Mt Lewis, but was present at $800 \mathrm{~m}$ at our three most southern transects. This heterogeneity in response could have numerous drivers and relate as much to resilience to initial epidemics as to factors influencing recovery. We note that the pattern of stronger recovery of L. rheocola in the northern most streams is consistent with warmer climates at these locations (particularly evident in the 
temperature logger data at Big Tableland). We speculate that complete loss of L. nannotis at Big Tableland and weak recovery at Mt Lewis could relate to comparatively small population sizes (see further below) and/or differences in genetic diversity at the northern extremity of the species range, with resulting differences in capacity for recovery. Genetic divergence occurs between populations of L. rheocola and L. nannotis on either side of the Black Mountain Corridor (Schneider et al. 1998, Bell et al. 2012), which splits our two most northern transects from the three southern transects, so genetic differences in immunity to $B d$ are possible between these groups.

In concordance with several other recent studies in the Wet Tropics (e.g. Phillott et al. 2013, Roznik et al. 2015), our study showed that exposure to cooler temperature regimes strongly increases the probability of infection by $B d$ for our focal species. However, our study provides unique insights into the thermal gradients used by these species across their current and former range. Elevation was a strong driver of temperature regimes among our sites, with mean monthly midnight air temperatures dropping by $\sim 1^{\circ} \mathrm{C}$ for every $200 \mathrm{~m}$ increase in elevation. Nevertheless, temperature differences between neighbouring survey elevations (those on the same stream) varied, with the largest drops in mean monthly midnight temperature observed between $400 \mathrm{~m}$ and $600 \mathrm{~m}$ at Mt Lewis and Big Tableland, and between $200 \mathrm{~m}$ and $400 \mathrm{~m}$ at Ethel Creek (and, to a lesser extent, at Murray-Kirrama; Figure 4). The reason for the greater temperature differences between consecutive elevational steps at some locations is uncertain, but this non-linear response of temperature to elevation may impact infection dynamics and result in thermally-driven disease barriers, which could explain variation in the ability of species to recolonise the uplands from lower elevation sites due to a steeper gradient of selection pressure at these low- to midelevations. Given the strong influence of temperature regimes on $B d$ infection prevalence, and the apparent continued intolerance of $L$. dayi to the pathogen, thermally-driven disease barriers to upper elevational migration appear particularly strong for this species.

Canopy cover was an important predictor of stream-side air temperature regimes across our study sites, with mean monthly midnight air temperatures estimated to decrease roughly $0.4^{\circ} \mathrm{C}$ for every $10 \%$ increase in canopy cover (Figure 5). With an observed canopy gradient between $45 \%$ and $95 \%$, this means a $2^{\circ} \mathrm{C}$ difference between high and low canopy sites an given 
elevation, on average across our study area. This variation is significantly less than that across the elevation gradient, but could still be consequential for $B d$ infection dynamics. According to our data, infection probability drops sharply between a mean monthly air temperature of $16^{\circ} \mathrm{C}$ to $18^{\circ} \mathrm{C}$ (from roughly $75 \%$ to $35 \%$, on average across species; Figure 6). Hence, sites at the same elevation but at opposite ends of the canopy spectrum could display significantly different infection rates (see Figure 7), with resulting implications for mortality rates and population persistence. A previous Wet Tropics study (Roznik 2013) demonstrated that the proportion of time that $L$. serrata, L. nannotis and L. rheocola were exposed to temperatures below $16^{\circ} \mathrm{C}$ was a strong predictor of infection status, and impairment of frog immune response under cooler conditions (Rollins-Smith et al. 2011) means that mortality rates are often highest at such temperatures (Berger et al. 2004, Murray et al. 2009, Phillott et al. 2013). While none of our sites above 200 m elevation had canopy cover below 70\%, small patches of open canopy habitat with consequent warmer temperatures likely exist across the elevational gradient. These may play a role in the recovery and persistence of frogs (Puschendorf 2009, Daskin et al. 2011, Puschendorf et al. 2011, Roznik et al. 2015), particularly at elevations of $\sim 600 \mathrm{~m}$ where $16^{\circ} \mathrm{C}$ is a common night time temperature for several consecutive months in the year (Figure 4).

In addition to these site-scale environmental drivers of disease risk, population recovery following $B d$ epizootics is likely determined by various factors relating to landscape context and connectivity, such as the regional extent of species loss, proximity to nearest refuge populations from which recolonization can occur and continuity of habitat to provide connectivity (Van Looy et al. 2019). Where there is species extirpation from an area, and a lack of connectivity to nearby areas where frogs persist, recolonization would be very difficult over longer time scales. Our study suggests this may be the case for L. nannotis at Big Tableland, and L. dayi at both Big Tableland and Ethel Creek, as a tidal river south of Big Tableland and an expanse of agricultural land north of Ethel Creek represent significant barriers for these species.

Within streams, we observed no areas of entirely unsuitable habitat, nor major landforms that would prevent frog dispersal between sites. Hence, in addition to the importance of the gradient in disease risk for determining recolonization rates, we speculate that immigration rate may as yet be inadequate to drive recolonization of some sites by our focal species across the Wet 
524 Tropics. In support of this, we found that species which were well below their former upland 525 distribution at some streams were also observed at low abundance in the lowland part of these streams, and this would result in reduced export of migrants to higher elevations. For example,

527 low numbers of $L$. rheocola were observed in the low elevation sites at Murray-Kirrama (where

528 the species was not seen above $400 \mathrm{~m}$ ) and few L. nannotis were observed at the low elevation sites at Mt Lewis (at which the species was not seen above $500 \mathrm{~m}$ ). It seems quite plausible in this case that heterogeneity between sites in apparent recolonization success may be due to small refuge population sizes resulting from ongoing impacts of chytridiomycosis in these refuges (Phillott et al. 2013, Grogan et al. 2016), as well as other ecological or genetic factors that constrain population growth rates (Savage et al. 2015, McKnight et al. 2019).

Of course, there are likely to be various other epidemiological, immunological, demographic and genetic factors that influence the patterns of recovery (or non-recovery) documented during this study and these may display considerable site-specificity. Attenuation of $B d$ virulence with time has been frequently hypothesised as a factor that may allow frogs to recover (Berger et al. 2016, McKnight et al. 2017, Scheele et al. 2017b); however, this remains unsupported with evidence favouring host factors such as evolution of innate immune defences (Voyles et al. 2018), including production of antifungal compounds by cutaneous bacterial symbionts (Harris et al. 2009, Becker et al. 2015, Kueneman et al. 2016, Bell et al. 2018), increased recruitment (Phillott et al. 2013, Brannelly et al. 2016, Scheele et al. 2017c), behavioural changes (Richards-Zawacki 2010, Puchendorf et al. 2011, Rowley and Alford 2013) and increases in genetic diversity (McKnight et al.2019). Adaptive immune defences have not yet been identified in Australian Wet Tropics frogs, although there is evidence of an adaptive immune response in other

548 be upregulated in susceptible frog species under heavy selection pressure from $B d$ (reviewed in 549 Fu and Waldman 2017, Eskew et al. 2018). Lastly, we highlight the possibility that the failure of

550 L. dayi, L. nannotis and L. rheocola to recover to the extent of L. serrata could result from the 551 latter now acting as a reservoir host for $B d$, having recovered more quickly than its congeners 552 and now being able to tolerate both high infection prevalence and intensity. The presence of 553 reservoir hosts that harbour high $B d$ loads is an important determinant of population suppression 
554 in other Australian frogs that can be infected by the pathogen (Scheele et al. 2017a, Brannelly et 555 al. 2018).

557 Lowland refugial amphibian populations played a critical role in the persistence of our focal 558 species following initial epizootics at higher elevations, and have an ongoing role in the persistence of L. dayi, L. nannotis and L. rheocola. Protection of these populations and appropriate management to mitigate broader threatening processes is vital, particularly at sites with high-quality habitat that may play a disproportionate role in maintaining genetic diversity (McKnight et al. 2019). We suggest that population connectivity along a disease risk gradient has been vital to the persistence and recovery of our focal species, analogous to the case for

564 Hawaiian Honeycreepers recovering from avian malaria (Atkinson et al. 2013, Guillaumet et al. 2017). Hence, maintaining the capacity for individuals to migrate from refuge populations to

566 higher risk locations should be a fundamental management priority.

At some sites, translocations could be trialled as a possible management intervention to facilitate the recovery of our focal species (Cayuela et al. 2019). Translocations have potential to amplify effects of natural selection by overcoming barriers, such as natural obstacles or an overly steep

572 phenotypes. These efforts could be combined with assisted selection or targeting of frogs that

573 have undergone natural selection. Translocation to unoccupied lowland sites could be pursued

574 for L. dayi and L. nannotis, at Big Tableland and Ethel Creek for the former, and Big Tableland

575 for the latter (locations at which these species were historically recorded but are no longer 576 found). Additionally, translocations to less densely occupied sites could be used to increase 577 abundance and facilitate natural recolonization, with priorities being L. rheocola at Murray-

578 Kirrama and L. nannotis at Mt Lewis. Likewise, experimental elevational translocations could 579 also be trialled at these sites to facilitate recovery. Such translocation efforts could be aided by management actions that seek to reduce disease risk. 582 While canopy reduction to increase insolation may increase temperatures sufficiently to reduce 583 disease risk in lowland and mid-elevation sites (see Roznik et al. 2015), the broader impacts of such activities may render it unsuitable. A recently suggested alternative is the use of localised 
609

610

611

612

613

614

615

warming through artificial heat sources (Hettyey et al. 2019), which has the potential to reduce the disease risk gradient at sites where microclimatic barriers (non-linear responses in temperature that may predict greater disease risk) are too great, optimising opportunity for host selection. However, such warming initiatives may be unnecessary in the face of climate change, as possible vegetation and canopy changes (Kearney et al. 2009) may break down these microclimatic barriers. Therefore, careful evaluation of translocation and warming initiatives is imperative, judging potential benefits against feasibility, cost, and broader environmental impacts.

Seeking to understand recovery mechanisms may reveal pathways to facilitate natural recovery. For some of our focal species (particularly L. dayi), and others with enzootic chytridiomycosis in eastern Australia, critical knowledge gaps remain in the areas of immune defence, the roles of microhabitat use and thermoregulation in mitigating pathogen virulence, and life history shifts that enable demographic compensation for heightened adult mortality. We suggest further field research to evaluate changes in microhabitat use or life history shifts in remnant populations that facilitate persistence, and laboratory experiments to determine if variation in innate immunity between populations explains differences in recovery patterns. Experiments that reveal the mechanisms underpinning the ability of L. serrata to withstand high $B d$ loads would be worthwhile. Further upland recolonizations seem probable for L. rheocola and L. nannotis given time, but recovery in $L$. dayi remains uncertain. It is worth cautioning that there may be thresholds of adaptability that prevent further unassisted recovery. The above research initiatives, coupled with ongoing monitoring of declined species, will provide important insights into the ecological response of these frogs to $B d$, and management actions that could further facilitate recovery.

\section{Acknowledgements}

We thank Keith McDonald for sharing his knowledge to help plan these surveys. Field work assistance was provided by Betsy Roznik, Katrin Schmidt, Karen Chong-Seng, Phil Bourke, Richard Duffy, Rachel Duffy, Alastair Freeman, Steve Johnson, Felicia King, Daniel Lenger, Sasha Greenspan and Kallum Jones. Michael Scroggie provided helpful discussions and 
616

617

618

619

620

621

622

623

624

625

626

627

628

629

630

631

632

633

634

635

636

637

638

639

640

641

642

643

644

645

statistical guidance during the preparation of this manuscript. Funding was provided by Australian Research Council grants to LB and LS (FT100100375 and LP110200240), and an Institute for Land, Water and Society Research Centre Fellowship (Charles Sturt University) to GH. SB, LS and LB conceived and designed the study, SB and LS collected the data, GH analysed data, SB, GH and LB wrote the manuscript and all authors edited the manuscript. This study was conducted in compliance with the Australian Code of Practice for the Care and Use of Animals for Scientific Purposes, 8th Edition, 2013, the Queensland Animal Care and Protection Act, 2001 and the Queensland Nature Conservation Act, 1992. Approval was granted for this study from James Cook University Animal Ethics Committee (A1820) and the Queensland government (scientific permit numbers WITK12035312 and WISP12035412). Access to Big Tableland (Ngalba Bulal National Park) was approved by Lee Yeatman, CEO of Jabalbina Yalanji Aboriginal Corporation.

\section{Literature Cited}

Atkinson, C.T., K. S. Saili, R. B. Utzurrum, and S. I. Jarvi. 2013. Experimental evidence for evolved tolerance to avian malaria in a wild population of low elevation Hawai'i 'Amakihi (Hemignathus virens). Ecohealth 10:366-375.

Bataille, A., S. D. Cashins, L. Grogan, L. F. Skerratt, D. Hunter, M. McFadden, B. Scheele, L. A. Brannelly, A. Macris, P. S. Harlow, S. Bell, L. Berger, and B. Waldman. 2015. Susceptibility of amphibians to chytridiomycosis is associated with MHC class II conformation. Proceedings of the Royal Society B: Biological Sciences 282:20143127.

Becker, M. H., J. B. Walke, S. Cikanek, A. E. Savage, N. Mattheus, C. N. Santiago, K. P. C. Minbiole, R. N. Harris, L. K. Belden, and B. Gratwicke. 2015. Composition of symbiotic bacteria predicts survival in Panamanian golden frogs infected with a lethal fungus. Proceedings of the Royal Society B: Biological Sciences 282:20142881.

Bell, R. C., J. B. MacKenzie, M. J. Hickerson, K. L. Chavarria, M. Cunningham, S. Williams, and C. Moritz. 2012. Comparative multi-locus phylogeography confirms multiple vicariance events in co-distributed rainforest frogs. Proceedings of the Royal Society B: Biological Sciences 279:991-999. 
Bell, S. C., S. Garland, and R. A. Alford. 2018. Increased numbers of culturable inhibitory bacterial taxa may mitigate the effects of Batrachochytrium dendrobatidis in Australian Wet Tropics frogs. Frontiers in Microbiology 9:1604.

Bell, S. C., G. W. Heard, L. Berger, and L. F. Skerratt. 2019. Data and code for 'Connectivity over a disease gradient enables recovery of rainforest frogs' [Data set]. Zenodo. http://doi.org/10.5281/zenodo.3402153.

Berger, L., A. A. Roberts, J. Voyles, J. E. Longcore, K. A. Murray, and L. F. Skerratt. 2016. History and recent progress on chytridiomycosis in amphibians. Fungal Ecology 19:8999.

Berger, L., R. Speare, P. Daszak, D. E. Green, A. A. Cunningham, C. L. Goggin, R. Slocombe, M. A.Ragan, A. D. Hyatt, K. R. McDonald, H. B. Hines, K. R. Lips, G. Marantelli, and H. Parkes. 1998. Chytridiomycosis causes amphibian mortality associated with population declines in the rain forests of Australia and Central America. Proceedings of the National Academy of Sciences of the United States of America 95:9031-9036.

Berger, L., R. Speare, H. B. Hines, G. Marantelli, A. D. Hyatt, K. R. McDonald, L. F. Skerratt, V. Olsen, J. M. Clarke, G. Gillespie, M. Mahony, N. Sheppard, C. Williams, and M. J. Tyler. 2004. Effect of season and temperature on mortality in amphibians due to chytridiomycosis. Australian Veterinary Journal 82:434-439.

Boyle, D. G., D. B. Boyle, V. Olsen, J. A. T. Morgan, and A. D. Hyatt. 2004. Rapid quantitative detection of chytridiomycosis (Batrachochytrium dendrobatidis) in amphibian samples using real-time Taqman PCR assay. Diseases of Aquatic Organisms 60:141-148.

Brannelly, L. A., R. Webb, L. F. Skerratt, and L. Berger. 2016. Amphibians with infectious disease increase their reproductive effort: evidence for the terminal investment hypothesis. Open Biology 6:150251.

Brannelly, L. A., R. J. Webb, D. A. Hunter, N. Clemann, K. Howard, L. F. Skerratt, L. Berger, and B. C. Scheele. 2018. Non-declining amphibians can be important reservoir hosts for amphibian chytrid fungus. Animal Conservation 21:91-101.

Burnham, K. P., and D. R. Anderson. 2002. Model selection and multimodel inference: a practical information-theoretic approach. 2nd edition. Springer, New York.

This article is protected by copyright. All rights reserved 
Cayuela, H., L. Gillet, A. Laudelout, A. Besnard, E. Bonnaire, P. Levionnois, E. Muths, M. Dufrêne, and T. Kinet. 2019. Survival cost to relocation does not reduce population selfsustainability in an amphibian. Ecological Applications 29:e01909.

Colhoun, J.1973. Effects of Environmental Factors on Plant Disease. Annual Review of Phytopathology 11:343-364.

Daskin, J. H., R. A. Alford, and R. Puschendorf. 2011. Short-term exposure to warm microhabitats could explain amphibian persistence with Batrachochytrium dendrobatidis. PLOS ONE 6:e26215.

Daversa, D. R., A. Fenton, A. I. Dell, T. W. J. Garner, and A. Manica. 2017. Infections on the move: how transient phases of host movement influence disease spread. Proceedings of the Royal Society B-Biological Sciences 284:20181807.

Eskew, E. A., B. C. Shock, E. E. B. LaDouceur, K. Keel, M. R. Miller, J. E. Foley, and B. D. Todd. 2018. Gene expression differs in susceptible and resistant amphibians exposed to Batrachochytrium dendrobatidis. Royal Society Open Science 5:170910.

Flory, A. R., S. Kumar, T. J. Stohlgren, and P. M. Cryan. 2012. Environmental conditions associated with bat white-nose syndrome mortality in the north-eastern United States. Journal of Applied Ecology 49:680-689.

Frazer, G. W., C. D. Canham, and K. P. Lertzman. 1999. Gap Light Analyzer (GLA), Version 2.0: Imaging software to extract canopy structure and gap light transmission indices from true-colour fisheye photographs, users manual and program documentation. Copyright $(\mathbb{C}$ 1999: Simon Fraser University, Burnaby, British Columbia, and the Institute of Ecosystem Studies, Millbrook, New York.

Fu, M. J., and B. Waldman. 2017. Major histocompatibility complex variation and the evolution of resistance to amphibian chytridiomycosis. Immunogenetics 69:529-536.

Garland, S., A. Baker, A. D. Phillott, and L. F. Skerratt. 2010. BSA reduces inhibition in a TaqMan (R) assay for the detection of Batrachochytrium dendrobatidis. Diseases of Aquatic Organisms 92:113-116.

Gog, J., R. Woodroffe, and J. Swinton. 2002. Disease in endangered metapopulations: the importance of alternative hosts. Proceedings of the Royal Society B-Biological Sciences 269:671-676. 
Gonzalez-Quevedo, C., R. G. Davies, and D. S. Richardson. 2014. Predictors of malaria infection in a wild bird population: landscape-level analyses reveal climatic and anthropogenic factors. Journal of Animal Ecology 83:1091-1102.

Greenspan, S. E., D. S. Bower, R. J. Webb, E. A. Roznik, L. A. Stevenson, L. Berger, G. Marantelli, D. A. Pike, L. Schwarzkopf, and R. A. Alford. 2017. Realistic heat pulses protect frogs from disease under simulated rainforest frog thermal regimes. Functional Eeology 31:2274-2286.

Grogan, L. F., A. D. Phillott, B. C. Scheele, L. Berger, S. D. Cashins, S. C. Bell, R. Puschendorf, and L. F. Skerratt. 2016. Endemicity of chytridiomycosis features pathogen overdispersion. Journal of Animal Ecology 85:806-816.

Guillaumet, A., W. A. Kuntz, M. D. Samuel, and E. H. Paxton. 2017. Altitudinal migration and the future of an iconic Hawaiian honeycreeper in response to climate change and management. Ecological Monographs 87:410-428.

Harding, K. C., M. Begon, A. Eriksson, and B. Wennberg. 2012. Increased migration in hostpathogen metapopulations can cause host extinction. Journal of Theoretical Biology 298:1-7.

Harris, R. N., R. M. Brucker, J. B. Walke, M. H. Becker, C. R. Schwantes, D. C. Flaherty, B. A. Lam, D. C. Woodhams, C. J. Briggs, V. T. Vredenburg, and K. P. C. Minbiole. 2009. Skin microbes on frogs prevent morbidity and mortality caused by a lethal skin fungus. The ISME Journal 3:818-824.

Harvell, C. D., C. E. Mitchell, J. R. Ward, S. Altizer, A. P. Dobson, R. S. Ostfeld, and M. D. Samuel. 2002. Ecology - Climate warming and disease risks for terrestrial and marine biota. Science 296:2158-2162.

Heard, G. W., C.D. Thomas, J. A. Hodgson, M. P. Scroggie, D. S. L. Ramsey, and N. Clemann. 2015. Refugia and connectivity sustain amphibian metapopulations afflicted by disease. Ecology Letters 18:853-863.

Hess, G. 1996. Disease in metapopulation models: Implications for conservation. Ecology 77:1617-1632.

Hettyey, A., J. Ujszegi, D. Herczeg, D. Holly, J. Vörös, B. R. Schmidt, and J. Bosch. 2019. Mitigating disease impacts in amphibian populations: Capitalizing on the thermal 
optimum mismatch between a pathogen and its host. Frontiers in Ecology and Evolution $7: 254$

Hosmer, D. W., S. Lemeshow, and R. X. Sturdivant. 2013. Applied Logistic Regression. 3rd edition. John Wiley and Sons, New Jersey.

Ingram, G. J., and K. R. McDonald. 1993. An update on the decline of Queensland's frogs. Pages 297-303 in L. D and A. D, editors. Herpetology in Australia: a diverse discipline. Royal Zoological Society of New South Wales, Mosman, NSW, Australia.

Jousimo, J., A. J. M. Tack, O. Ovaskainen, T. Mononen, H. Susi, C. Tollenaere, and A. L. Laine. 2014. Ecological and evolutionary effects of fragmentation on infectious disease dynamics. Science 344:1289-1293.

Kearney, M., R. Shine and W. P. Porter. 2009. The potential for behavioral thermoregulation to buffer "cold-blooded" animals against climate warming. Proceedings of the National Academy of Sciences 106:3835-3840.

Knapp, R. A., G. M. Fellers, P. M. Kleeman, D. A. W. Miller, V. T. Vredenburg, E. B. Rosenblum, and C. J. Briggs. 2016. Large-scale recovery of an endangered amphibian despite ongoing exposure to multiple stressors. Proceedings of the National Academy of Sciences of the United States of America 113:11889-11894.

Kueneman, J. G., D. C. Woodhams, W. Van Treuren, H. M. Archer, R. Knight, and V. J. McKenzie. 2016. Inhibitory bacteria reduce fungi on early life stages of endangered Colorado boreal toads (Anaxyrus boreas). Isme Journal 10:934-944.

Link, W.A., and Eaton M.J. (2012). On thinning of chains in MCMC. Methods in Ecology and Evolution 3:112-115.

McDonald, K., and R. Alford. 1999. A review of Declining Frogs in Northern Queensland. Pages 14-22 in A. Campbell, editor. Declines and disappearances of Australian frogs. Environment Australia.

McDonald, K. R. 1994. Declining frog populations in the Wet Tropics. Internal report. Conservation Strategy Branch, Queensland Department of Environment and Heritage, Atherton, Queensland.

McDonald, K. R., D. Méndez, R. Müller, A. B. Freeman, and R. Speare. 2005. Decline in the prevalence of chytridiomycosis in upland frog populations in North Queensland, Australia. Pacific Conservation Biology 11:114-129. 
McKnight, D. T., R. A. Alford, C. J. Hoskin, L. Schwarzkopf, S. E. Greenspan, K. R. Zenger, and D. S. Bower. 2017. Fighting an uphill battle: the recovery of frogs in Australia's Wet Tropics. Ecology 98:3221-3223.

McKnight, D. T., M. M. Lal, D. S. Bower, L. Schwarzkopf, R. A. Alford, and K. R. Zenger. 2019. The return of the frogs: The importance of habitat refugia in maintaining diversity during a disease outbreak. Molecular Ecology 28:2731-2745.

Meyer, E. A., R. L. Cramp, M. H. Bernal, and C. E. Franklin. 2012. Changes in cutaneous microbial abundance with sloughing: possible implications for infection and disease in amphibians. Diseases of Aquatic Organisms 101:235-242.

Murray, K. A., R. W. R. Retallick, R. Puschendorf, L. F. Skerratt, D. Rosauer, H. I. McCallum, L. Berger, R. Speare, and J. VanDerWal. 2011. Assessing spatial patterns of disease risk to biodiversity: implications for the management of the amphibian pathogen, Batrachochytrium dendrobatidis. Journal of Applied Ecology 48:163-173.

Murray, K. A., L.F. Skerratt, S. Garland, D. Kriticos, and H. McCallum. 2013. Whether the weather drives patterns of endemic amphibian chytridiomycosis: A pathogen proliferation approach. PLoS ONE 8:e61061.

Murray, K. A., L. F. Skerratt, R. Speare, and H. McCallum. 2009. Impact and dynamics of disease in species threatened by the amphibian chytrid fungus, Batrachochytrium dendrobatidis. Conservation Biology 23:1242-1252.

Muths, E., R. D. Scherer, and D. S. Pilliod. 2011. Compensatory effects of recruitment and survival when amphibian populations are perturbed by disease. Journal of Applied Ecology 48:873-879.

Newell, D. A., R. L. Goldingay, and L. O. Brooks. 2013. Population recovery following decline in an endangered stream-breeding frog (Mixophyes fleayi) from subtropical Australia. PLOS ONE 8:e58559.

O’Hanlon, S. J., A. Rieux, R. A. Farrer, G. M. Rosa, B. Waldman, A. Bataille, T. A. Kosch, K. A. Murray, B. Brankovics, M. Fumagalli, M. D. Martin, N. Wales, M. Alvarado-Rybak, K. A. Bates, L. Berger, S. Böll, L. Brookes, F. Clare, E. A. Courtois, A. A. Cunningham, T. M. Doherty-Bone, P. Ghosh, D. J. Gower, W. E. Hintz, J. Höglund, T. S. Jenkinson, C.-F. Lin, A. Laurila, A. Loyau, A. Martel, S. Meurling, C. Miaud, P. Minting, F. Pasmans, D. S. Schmeller, B. R. Schmidt, J. M. G. Shelton, L. F. Skerratt, F. Smith, C. 
Soto-Azat, M. Spagnoletti, G. Tessa, L. F. Toledo, A. Valenzuela-Sánchez, R. Verster, J. Vörös, R. J. Webb, C. Wierzbicki, E. Wombwell, K. R. Zamudio, D. M. Aanensen, T. Y. James, M. T. P. Gilbert, C. Weldon, J. Bosch, F. Balloux, T. W. J. Garner, and M. C. Fisher. 2018. Recent Asian origin of chytrid fungi causing global amphibian declines. Science 360:621-627.

Phillott, A. D., L.F. Grogan, S. D. Cashins, K. R. McDonald, L. Berger, and L. F. Skerratt. 2013. Chytridiomycosis and seasonal mortality of tropical stream-associated frogs 15 years after introduction of Batrachochytrium dendrobatidis. Conservation Biology 27:1058-1068.

Piotrowski, J. S., S. L. Annis, and J. E. Longcore. 2004. Physiology of Batrachochytrium dendrobatidis, a chytrid pathogen of amphibians. Mycologia 96:9-15.

Puschendorf, R. 2009. Environmental effects on a host-pathogen system: Frogs and Batrachochytrium dendrobatidis in wet and dry habitat. Ph.D. Thesis. James Cook University, Townsville.

Puschendorf, R., F. Bolaños, and G. Chaves. 2006. The amphibian chytrid fungus along an altitudinal transect before the first reported declines in Costa Rica. Biological Conservation 132:136-142.

Puschendorf, R., A. C. Carnaval, J. VanDerWal, H. Zumbado-Ulate, G. Chaves, F. Bolanos, and R. A. Alford. 2009. Distribution models for the amphibian chytrid Batrachochytrium dendrobatidis in Costa Rica: proposing climatic refuges as a conservation tool. Diversity and Distributions 15:401-408.

Puschendorf, R., L. Hodgson, R. A. Alford, L. F. Skerratt, and J. VanDerWal. 2013. Underestimated ranges and overlooked refuges from amphibian chytridiomycosis. Diversity and Distributions 19:1313-1321.

Puschendorf, R., C. J. Hoskin, S. D. Cashins, K. McDonald, L. F. Skerratt, J. Vanderwal, and R. A. Alford 2011. Environmental refuge from disease-driven amphibian extinction. Conservation Biology 25:956-964.

R Core Team. 2018. R: A language and environment for statistical computing. R Foundation for Statistical Computing Vienna, Austria. http://www.r-project.org/. 
Richards-Zawacki, C. L. 2010. Thermoregulatory behaviour affects prevalence of chytrid fungal infection in a wild population of Panamanian golden frogs. Proceedings of the Royal Society B-Biological Sciences 277:519-528.

Richards, S. J., and R. A. Alford. 2005. Structure and dynamics of a rainforest frog (Litoria genimaculata) population in northern Queensland. Australian Journal of Zoology 53:229236.

Richards, S. J., K. R. McDonald, and R. A. Alford. 1993. Declines in populations of Australia's endemic tropical rainforest frogs. Pacific Conservation Biology 1:66-77.

Rollins-Smith, L. A. 2017. Amphibian immunity-stress, disease, and climate change. Developmental and Comparative Immunology 66:111-119.

Rollins-Smith, L. A., J. P. Ramsey, J. D. Pask, L. K. Reinert, and D. C. Woodhams. 2011. Amphibian immune defenses against chytridiomycosis: Impacts of changing environments. Integrative and Comparative Biology 51:552-562.

Rowley, J. J. L., and R. A. Alford. 2013. Hot bodies protect amphibians against chytrid infection in nature. Scientific Reports 3:1515.

Roznik, E. A. 2013. Effects of individual behaviour on host-pathogen interactions: Australian rainforest frogs and the chytrid fungus Batrachochytrium dendrobatidis. Ph.D. Thesis. James Cook University, Townsville.

Roznik, E. A., and R. A. Alford. 2012. Does waterproofing Thermochron iButton dataloggers influence temperature readings? Journal of Thermal Biology 37:260-264.

Roznik, E. A., S. J. Sapsford, D. A. Pike, L. Schwarzkopf, and R. A. Alford. 2015. Natural disturbance reduces disease risk in endangered rainforest frog populations. Scientific Reports 5:13472.

Samuel, M.D., P. H. F. Hobbelen, F. DeCastro, J. A. Ahumada, D. A. LaPointe, C. T. Atkinson, B. L. Woodworth, P. J. Hart, and D. C. Duffy. 2011. The dynamics, transmission, and population impacts of avian malaria in native Hawaiian birds: a modeling approach. Ecologieal Applications 21:2960-2973.

Sapsford, S. J., R. A. Alford, and L. Schwarzkopf. 2013. Elevation, Temperature, and aquatic connectivity all influence the infection dynamics of the amphibian chytrid fungus in adult frogs. PLoS ONE 8. 
Savage, A. E., C. G. Becker, and K. R. Zamudio. 2015. Linking genetic and environmental factors in amphibian disease risk. Evolutionary Applications 8:560-572.

Scheele, B., F. Guarino, W. Osborne, D. A. Hunter, L. F. Skerratt, and D. A. Driscoll. 2014. Decline and re-expansion of an amphibian with high prevalence of chytrid fungus. Biological Conservation 170:86-91.

Scheele, B. C., C. N. Foster, D. A. Hunter, D. B. Lindenmayer, B. R. Schmidt, and G. W. Heard. 2019. Living with the enemy: Facilitating amphibian coexistence with disease. Biological Conservation 236:52-59.

Scheele, B. C., D. A. Hunter, L. A. Brannelly, L. F. Skerratt, and D. A. Driscoll. 2017 a. Reservoir-host amplification of disease impact in an endangered amphibian. Conservation Biology 31:592-600.

Scheele, B. C., L. F. Skerratt, L. F. Grogan, D. A. Hunter, N. Clemann, M. McFadden, D. Newell, C. J. Hoskin, G. R. Gillespie, G. W. Heard, L. Brannelly, A. A. Roberts, and L. Berger. 2017b. After the epidemic: Ongoing declines, stabilizations and recoveries in amphibians afflicted by chytridiomycosis. Biological Conservation 206:37-46.

Scheele, B. C., L. F. Skerratt, D. A. Hunter, S. C. Banks, J. C. Pierson, D. A. Driscoll, P. G. Byrne, and L. Berger. 2017c. Disease-associated change in an amphibian life-history trait. Oecologia 184:825-833.

Schneider, C. J., M. Cunningham, and C. Moritz. 1998. Comparative phylogeography and the history of endemic vertebrates in the Wet Tropics rainforests of Australia. Molecular Ecology 7:487-498.

Skerratt, L. F., L. Berger, N. Clemann, D. A. Hunter, G. Marantelli, D. A. Newell, A. Philips, M. McFadden, H. B. Hines, B. C. Scheele, L. A. Brannelly, R. Speare, S. Versteegen, S. D. Cashins, and M. West. 2016. Priorities for management of chytridiomycosis in Australia: saving frogs from extinction. Wildlife Research 43:105-120.

Skerratt, L. F., L. Berger, H. B. Hines, K. R. McDonald, D. Mendez, and R. Speare. 2008. Survey protocol for detecting chytridiomycosis in all Australian frog populations. Diseases of Aquatic Organisms 80:85-94.

Skerratt, L. F., L. Berger, R. Speare, S. Cashins, K. R. McDonald, A. D. Phillott, H. B. Hines, and N. Kenyon. 2007. Spread of chytridiomycosis has caused the rapid global decline and extinction of frogs. Ecohealth 4:125-134. 
Skerratt, L. F., D. Mendez, K. R. McDonald, S. Garland, J. Livingstone, L. Berger, and R. Speare. 2011. Validation of diagnostic tests in wildlife: The case of chytridiomycosis in wild amphibians. Journal of Herpetology 45:444-450.

Snall, T., R. B. O'Hara, C. Ray, and S. K. Collinge. 2008. Climate-driven spatial dynamics of plague among prairie dog colonies. American Naturalist 171:238-248.

Spiegelhalter, D. J., N. G. Best, B. R. Carlin, and A. van der Linde. 2002. Bayesian measures of model complexity and fit. Journal of the Royal Statistical Society Series B-Statistical Methodology 64:583-616.

Spitzen-van der Sluijs, A., S. Canessa, A. Martel, and F. Pasmans. 2017. Fragile coexistence of a global chytrid pathogen with amphibian populations is mediated by environment and demography. Proceedings of the Royal Society B-Biological Sciences 284:20171444.

Stevenson, L. A., R. A. Alford, S. C. Bell, E. A. Roznik, L. Berger, and D. A. Pike. 2013. Variation in thermal performance of a widespread pathogen, the amphibian chytrid fungus Batrachochytrium dendrobatidis. PLoS ONE 8:e73830.

Thomas, A., B. O'Hara, U. Ligges, and S. Sturtz. 2006. Making BUGS Open. R News, 6, 12-17.

Thompson, J. N.1999. Specific hypotheses on the geographic mosaic of coevolution. The American Naturalist 153:S1-S14.

Trenerry, M.P., W. F. Laurance, and K. R. McDonald. 1994. Further evidence for the precipitous decline of endemic rainforest frogs in tropical Australia. Pacific Conservation Biology 1:150-153.

Van Looy, K., J. D. Tonkin, M. Floury, C. Leigh, J. Soininen, S. Larsen, J. Heino, N. LeRoy Poff, M. Delong, S. C. Jähnig, T. Datry, N. Bonada, J. Rosebery, A. Jamoneau, S. J. Ormerod, K. J. Collier, and C. Wolter. 2019. The three Rs of river ecosystem resilience: Resources, recruitment, and refugia. River Research and Applications 35:107-120. van Riper III, C., S. G. van Riper, M. L. Goff, and M. Laird. 1986. The epizootiology and ecological significance of malaria in Hawaiian land birds. Ecological Monographs 56:327-344.

Verant, M. L., J. G. Boyles, W. Waldrep, Jr., G. Wibbelt, and D. S. Blehert. 2012. Temperaturedependent growth of Geomyces destructans, the fungus that causes bat white-nose syndrome. PLoS ONE 7:e46280. 
Voyles, J., D. C. Woodhams, V. Saenz, A. Q. Byrne, R. Perez, G. Rios-Sotelo, M. J. Ryan, M. C. Bletz, F. A. Sobell, S. McLetchie, L. Reinert, E. B. Rosenblum, L. A. Rollins-Smith, R. Ibáñez, J. M. Ray, E. J. Griffith, H. Ross, and C. L. Richards-Zawacki. 2018. Shifts in disease dynamics in a tropical amphibian assemblage are not due to pathogen attenuation. Science 359:1517.

Woodhams, D. C., and R. A. Alford. 2005. Ecology of chytridiomycosis in rainforest stream frog assemblages of tropical Queensland. Conservation Biology 19:1449-1459.

Woodhams, D. C., R. A. Alford, and G. Marantelli. 2003. Emerging disease of amphibians cured by elevated body temperature. Diseases of Aquatic Organisms 55:65-67.

\section{Data Availability}

Code and data are available on Zenodo: http://doi.org/10.5281/zenodo.3402153

Table 1. The upland and lowland geopositions for each stream at which surveys were undertaken. Expected species are based on historical records from the five study regions (Figure 1). Species are: Litoria dayi (Ld), L. nannotis (Ln), L. rheocola (Lr) and Litoria serrata (Ls).

\begin{tabular}{|c|c|c|c|c|}
\hline Stream & Source of & $\begin{array}{l}\text { Lowland } \\
\text { coordinates }\end{array}$ & $\begin{array}{l}\text { Upland } \\
\text { coordinates }\end{array}$ & $\begin{array}{l}\text { Expected } \\
\text { species }\end{array}$ \\
\hline Big Tableland & $\begin{array}{l}\text { Mungumby } \\
\text { Creek }\end{array}$ & $-15.707 \mathrm{~S} 145.2557 \mathrm{E}$ & $-15.711 \mathrm{~S} 145.2721 \mathrm{E}$ & Ld, Ln, Lr, Ls \\
\hline Mt Lewis & $\begin{array}{l}\text { South Mossman } \\
\text { River }\end{array}$ & $-16.516 \mathrm{~S} 145.3412 \mathrm{E}$ & $-16.508 \mathrm{~S} 145.2730 \mathrm{E}$ & $\mathrm{Ld}, \mathrm{Ln}, \mathrm{Lr}, \mathrm{Ls}$ \\
\hline Behana Gorge & Behana Creek & $-17.182 \mathrm{~S} 145.8264 \mathrm{E}$ & $-17.243 \mathrm{~S} 145.8487 \mathrm{E}$ & Ld, Ln, Lr, Ls \\
\hline Murray-Kirrama & Murray River & $-18.158 \mathrm{~S} 145.8234 \mathrm{E}$ & $-18.219 \mathrm{~S} 145.8058 \mathrm{E}$ & Ld, Ln, Lr, Ls \\
\hline Ethel Creek & Ethel Creek & $-18.984 \mathrm{~S} 146.2106 \mathrm{E}$ & $-18.997 \mathrm{~S} 146.1894 \mathrm{E}$ & Ld, Ln, Ls \\
\hline
\end{tabular}

Table 2. Parameter estimates for the model of stream-side air temperature at midnight, as recorded using data loggers. Posterior means are shown, along with the $95 \%$ credible interval (95\% CI) for each parameter. 


\begin{tabular}{|l|l|l|}
\hline Parameter / Effect & Mean & $\mathbf{9 5 \%}$ CI \\
\hline Intercept (Big Tableland) & 7.138 & $6.776,7.469$ \\
\hline Intercept (Mount Lewis) & 6.713 & $6.379,7.017$ \\
\hline Intercept (Behana Gorge) & 6.415 & $6.092,6.710$ \\
\hline Intercept (Murray-Kirrama) & 6.727 & $6.389,7.034$ \\
\hline Intercept (Ethel Creek) & 6.697 & $6.355,7.008$ \\
\hline cos(Date) & 0.493 & $0.419,0.564$ \\
\hline sin(Date) & 0.317 & $0.275,0.355$ \\
\hline Elevation & -1.008 & $-1.089,-0.923$ \\
\hline Canopy & -0.422 & $-0.508,-0.338$ \\
\hline Max air temperature (Big Tableland) & 0.682 & $0.491,0.877$ \\
\hline Max air temperature (Mount Lewis) & 0.533 & $0.428,0.641$ \\
\hline Max air temperature (Behana Gorge) & 0.782 & $0.557,0.996$ \\
\hline Max air temperature (Murray-Kirrama) & 1.137 & $0.979,1.291$ \\
\hline Max air temperature (Ethel Creek) & 0.767 & $0.648,0.879$ \\
\hline Autoregressive term & 0.657 & $0.641,0.674$ \\
\hline Stream-level standard deviation & 9.476 & $4.517,22.130$ \\
\hline
\end{tabular}

941 Table 3. Model selection statistics for the five models fit to the $B d$ infection data for each

942 species. Model selection statistics are the Deviance Information Criterion (DIC), distance from

943 the most parsimonious model ( $\triangle \mathrm{DIC})$ and model selection weight. The top-ranked model for 944 each species is highlighted in bold.

\begin{tabular}{|l|l|l|l|}
\hline Model & DIC & $\Delta$ DIC & Model weight \\
\hline Midnight temperature at capture & 432.5 & 19.8 & 0 \\
\hline Mean midnight temperature over 7 nights & 422.3 & 9.6 & 0.006 \\
\hline Mean midnight temperature over 14 nights & 416.8 & 4.1 & 0.093 \\
\hline Mean midnight temperature over 21 nights & 415.5 & 2.8 & 0.178 \\
\hline Mean midnight temperature over 28 nights & $\mathbf{4 1 2 . 7}$ & $\mathbf{0}$ & $\mathbf{0 . 7 2 3}$ \\
\hline
\end{tabular}


947 Table 4. Parameter estimates for the top-ranked infection model for each species. The temperature effect in these models is the average stream-side air temperature at midnight over 949 the preceding 28 nights (derived from loggers or predictions from the air temperature model 950 where logger data were missing). Posterior means are shown, along with the $95 \%$ credible interval $(95 \% \mathrm{CI})$ for each parameter.

952

953

954

955

956

957

958

959

\begin{tabular}{|l|l|l|l|}
\hline Species & Parameter /Effect & Mean & 95\% CI \\
\hline Litoria dayi & Intercept & -0.640 & $-1.756,0.448$ \\
\hline & Temperature & -2.145 & $-5.097,-0.256$ \\
\hline Litoria nannotis & Intercept & -0.371 & $-0.809,0.128$ \\
\hline & Temperature & -1.889 & $-2.647,-1.180$ \\
\hline Litoria rheocola & Intercept & -0.791 & $-1.279,-0.373$ \\
\hline & Temperature & -1.715 & $-2.744,-0.495$ \\
\hline Litoria serrata & Intercept & -0.711 & $-1.143,-0.339$ \\
\hline & Temperature & -2.049 & $-3.021,-1.239$ \\
\hline
\end{tabular}

Table 5. Model selection statistics for the three logistic regression models fit to the occupancy data for each species. Model selection statistics are the Deviance Information Criterion (DIC), distance from the most parsimonious model $(\Delta \mathrm{DIC})$ and model selection weight. The top model in each case is highlighted in bold.

\begin{tabular}{|l|l|l|l|l|}
\hline & Model & DIC & $\Delta$ DIC & $\begin{array}{l}\text { Model } \\
\text { weight }\end{array}$ \\
\hline Litoria dayi & Null & 29.570 & 13.500 & 0.001 \\
\hline & Predicted infection prevalence & $\mathbf{1 6 . 0 7 0}$ & $\mathbf{0}$ & $\mathbf{0 . 9 9 9}$ \\
\hline Litoria nannotis & Null & $\mathbf{1 9 . 6 1 0}$ & $\mathbf{0}$ & $\mathbf{0 . 6 9 4}$ \\
\hline & Predicted infection prevalence & 21.250 & 1.604 & 0.306 \\
\hline Litoria rheocola & Null & 33.380 & 7.260 & 0.026 \\
\hline
\end{tabular}




\begin{tabular}{|l|l|l|l|l|}
\hline & Predicted infection prevalence & $\mathbf{2 6 . 1 2 0}$ & $\mathbf{0}$ & $\mathbf{0 . 9 7 4}$ \\
\hline Litoria serrata & Null & 29.080 & 7.34 & 0.025 \\
\hline & Predicted infection prevalence & $\mathbf{2 1 . 7 4 0}$ & $\mathbf{0}$ & $\mathbf{0 . 9 7 5}$ \\
\hline
\end{tabular}

960

961

Table 6. Estimated effect of predicted $B d$ prevalence on the probability of site occupancy for each species. Posterior means are shown for both the intercept and effect, along with their 95\% credible intervals $(95 \% \mathrm{CI})$.

965

\begin{tabular}{|l|l|l|l|}
\hline Species & Parameter /Effect & Mean & $\mathbf{9 5 \% ~ C I ~}$ \\
\hline Litoria dayi & Intercept & 3.704 & $0.836,7.351$ \\
\hline & Predicted $B d$ prevalence & -15.270 & $-27.570,-5.561$ \\
\hline Litoria nannotis & Intercept & 2.414 & $0.021,5.334$ \\
\hline & Predicted $B d$ prevalence & -0.816 & $-7.122,5.787$ \\
\hline Litoria rheocola & Intercept & 3.870 & $1.402,7.050$ \\
\hline & Predicted $B d$ prevalence & -8.616 & $-16.640,-2.481$ \\
\hline Litoria serrata & Intercept & -0.521 & $-2.321,1.216$ \\
\hline & Predicted $B d$ prevalence & 10.750 & $3.039,20.620$ \\
\hline
\end{tabular}

Figure Captions

969 Figure 1. Historical spatial and elevational distribution of the four focal species in the Wet

970 Tropics prior to and during declines. Historical records (dots) were collated from the Queensland

971 Government's biodiversity atlas ('Wildnet') and reviews of published and unpublished sources.

972 Map color scale shows elevation in meters above sea level. The location of the five study regions

973 (triangles) is also shown, being Big Tableland (BT), Mount Lewis (ML), Behana Gorge (BG),

974 Murray-Kirrama (MK) and Ethel Creek (EC). Inset histograms show the elevational distribution

975 of historical records for each species. 
977 Figure 2. The elevational distribution of counts of each species during our surveys at Big

978 Tableland (BT), Mount Lewis (ML), Behana Gorge (BG), Murray-Kirrama (MK) and Ethel

979 Creek (EC). Counts are represented by dot size and color. For sites that received repeat surveys, 980 the average count is presented. Left-to-right ordering of regions is from the northern-most (Big 981 Tableland) to southern-most (Ethel Creek).

982

Figure 3. Histograms of $B d$ infection load among infected individuals of each species. Infection 984 load is the natural logarithm of estimated zoospore equivalents. Text in the upper right of each 985 plot gives the prevalence of infections (number infected vs. number tested).

986

Figure 4. The average monthly stream-side air temperature at midnight for sites across the 988 elevational gradient, recorded using data loggers between May 2013 and April 2014. Note that the highest site at Big Tableland was $600 \mathrm{~m}, 1000 \mathrm{~m}$ at Behana Gorge, and $800 \mathrm{~m}$ at both Murray-Kirrama and Ethel Creek. Missing sites below these elevations are the result of logger failure or loss. Top-to-bottom ordering of regions is from northern-most (Big Tableland) to southern-most (Ethel Creek). Note that the $200 \mathrm{~m}$ site at Behana Gorge (marked by an asterisk) was placed at $130 \mathrm{~m}$ due to a lack of suitable frog habitat at $200 \mathrm{~m}$.

Figure 5. Estimated relationship between elevation, canopy cover and mean monthly midnight air temperature at streams in the Wet Tropics during August. Estimates are derived from the model of midnight air temperatures produced using logger data and encompass the full potential range of canopy cover and elevation in the region (in reality, canopy cover increases with elevation; see Figure 8). Estimates are based on mean maximum daily temperature records for August 2013 from weather stations across the Wet Tropics, using the average intercept across

Figure 6. Relationships between mean midnight air temperature over the preceding 28 nights sites from which logger data were obtained. dashed lines the $95 \%$ credible interval. 
1007 Figure 7. Estimated relationships between elevation, canopy cover and $B d$ infection probability 1008 for each species in the Wet Tropics during August. Estimates are derived by first estimating 1009 mean monthly midnight air temperature across the elevational and canopy gradient (as in Figure 1010 5), and subsequently estimating infection probability for each species using the relationships 1011 depicted in Figure 6. Estimates are displayed across the full potential range of canopy cover and 1012 elevation in the Wet Tropics (in reality, canopy cover increases with increasing elevation; see

1013 Figure 8).

1014

1015 Figure 8. Relationships between predicted infection prevalence, site occupancy and both 1016 elevation and canopy cover for each species. Dots are sites at which each species was detected, 1017 located in two-dimensional space according to their elevation and canopy cover. Dot colour 1018 shows predicted seasonal $B d$ prevalence at these sites (between zero and one, as per the colour 1019 legend), derived by simulating the swabbing of 30 frogs / site / month between May 2013 and 1020 January 2014 (the survey period in this study; see the text for description of the simulation 1021 approach).

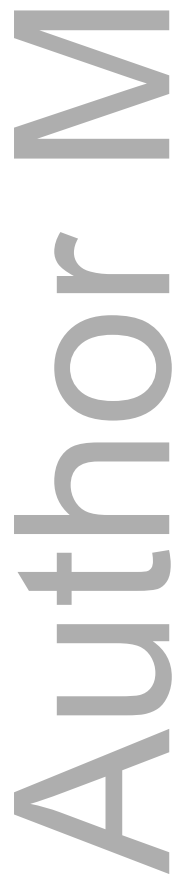

This article is protected by copyright. All rights reserved 


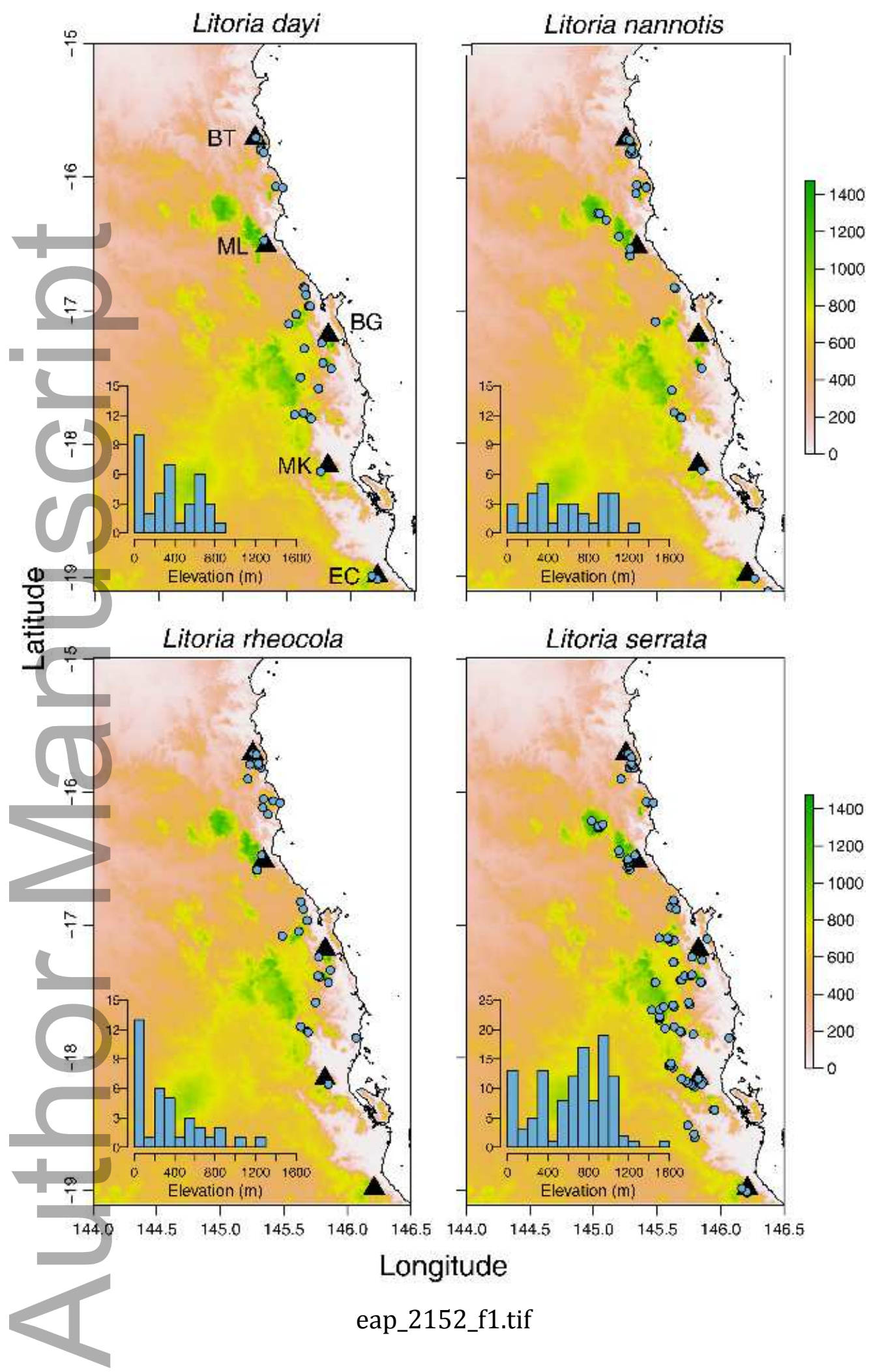

This article is protected by copyright. All rights reserved 

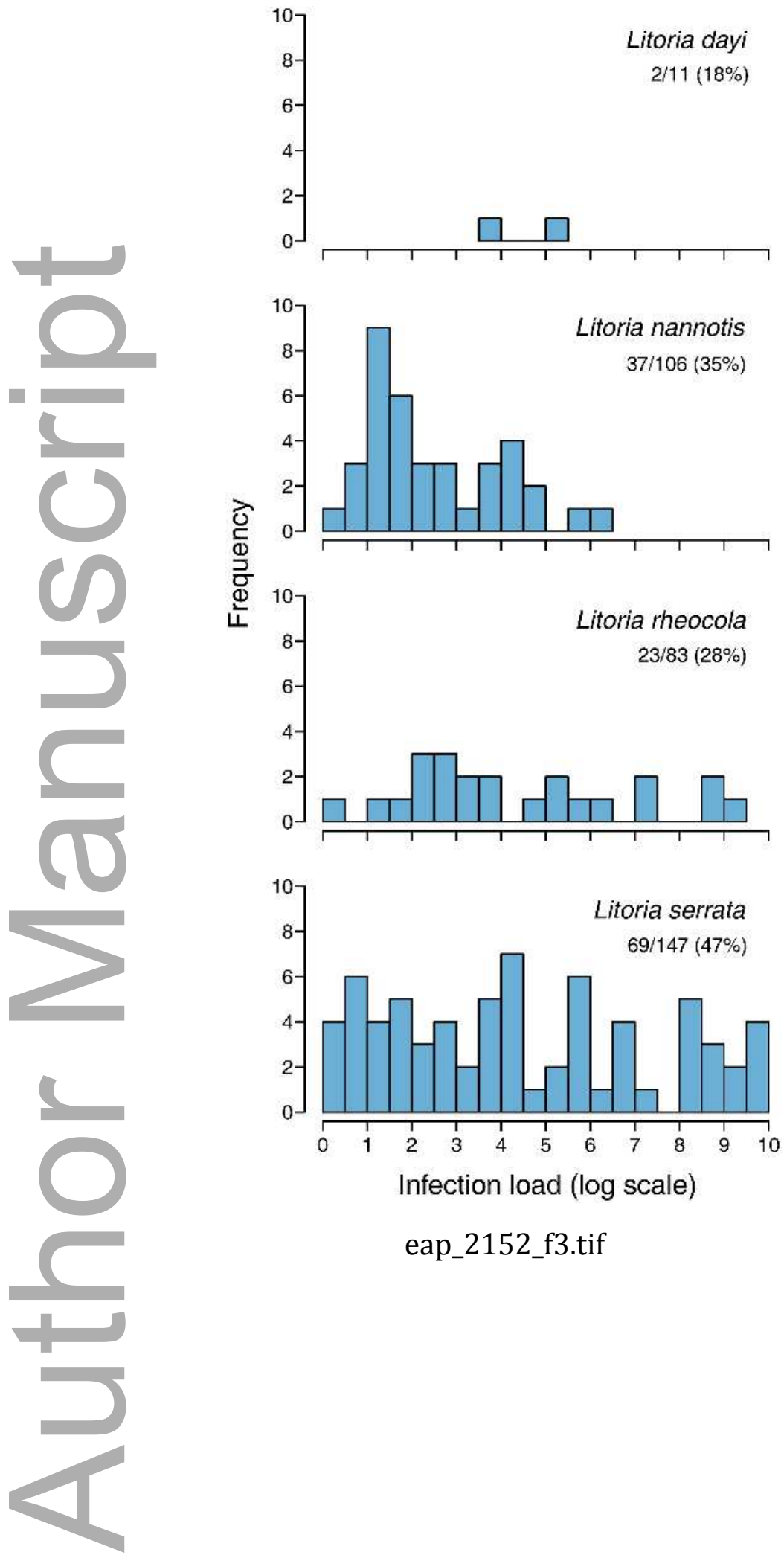

eap_2152_f3.tif 


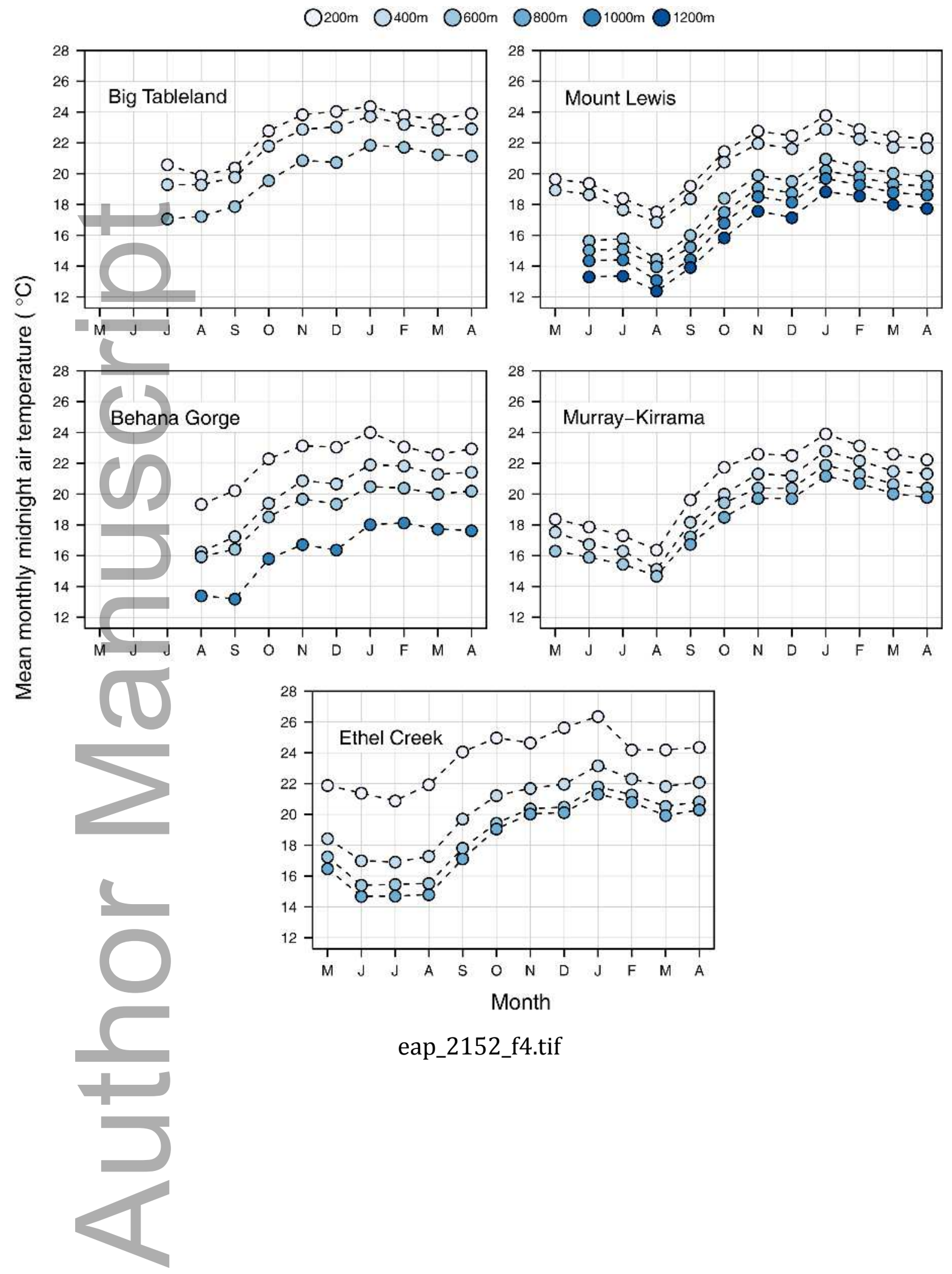

This article is protected by copyright. All rights reserved 

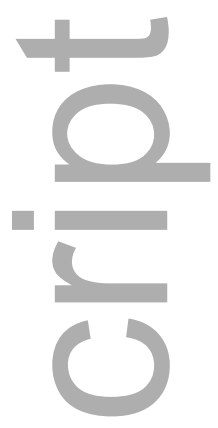

$\infty$

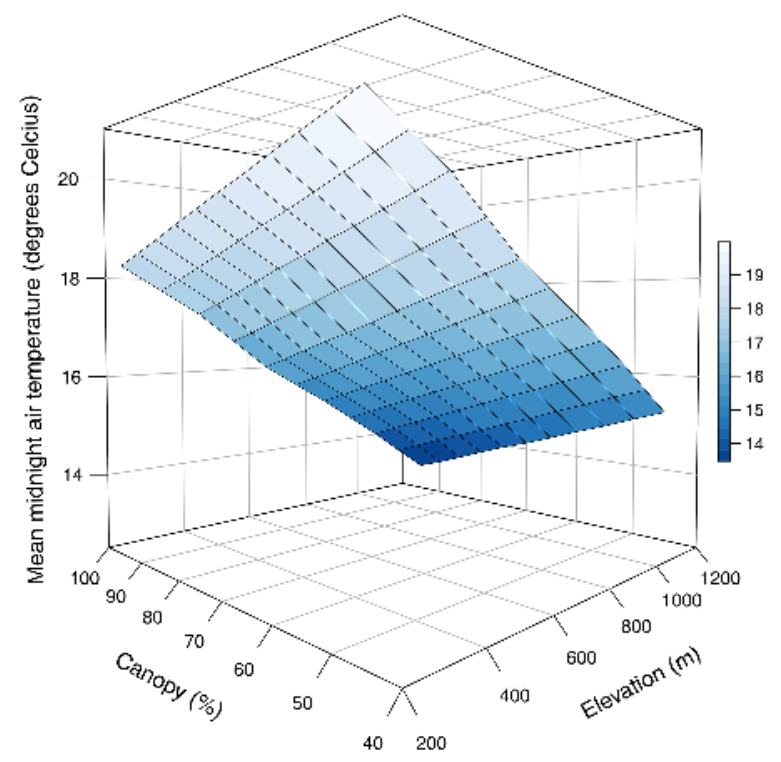

eap_2152_f5.tif
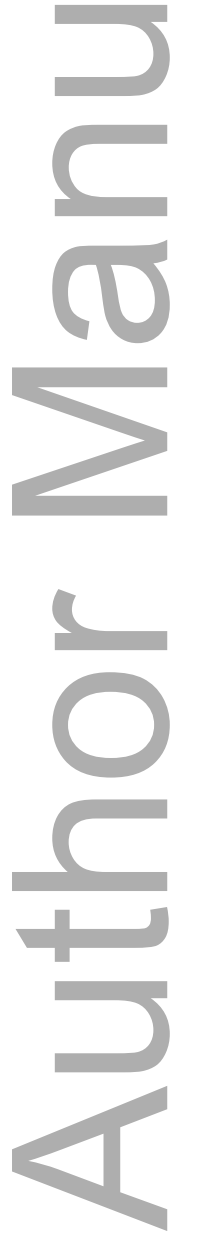

This article is protected by copyright. All rights reserved 

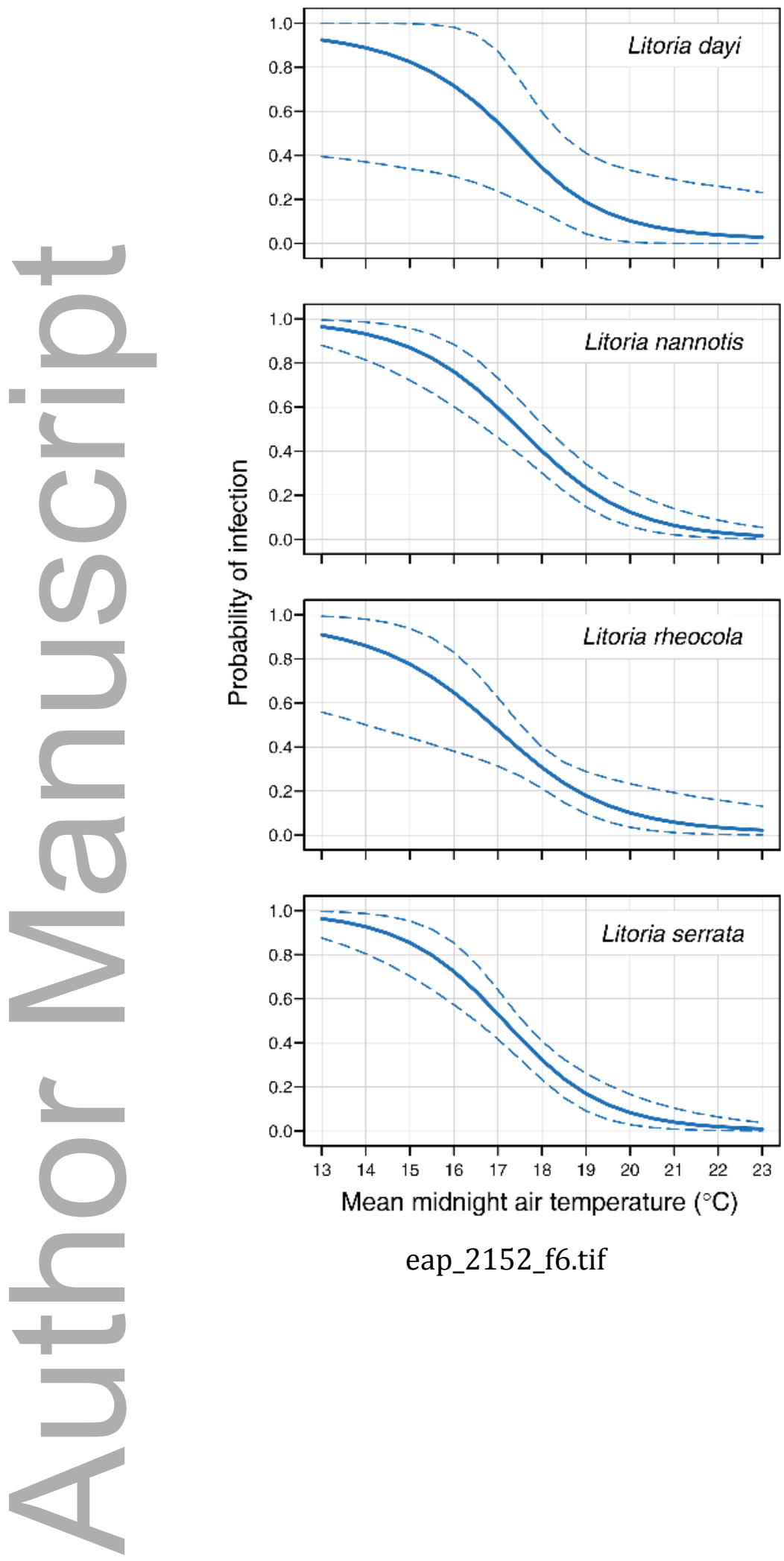

eap_2152_f6.tif 


\section{Litoria dayi}

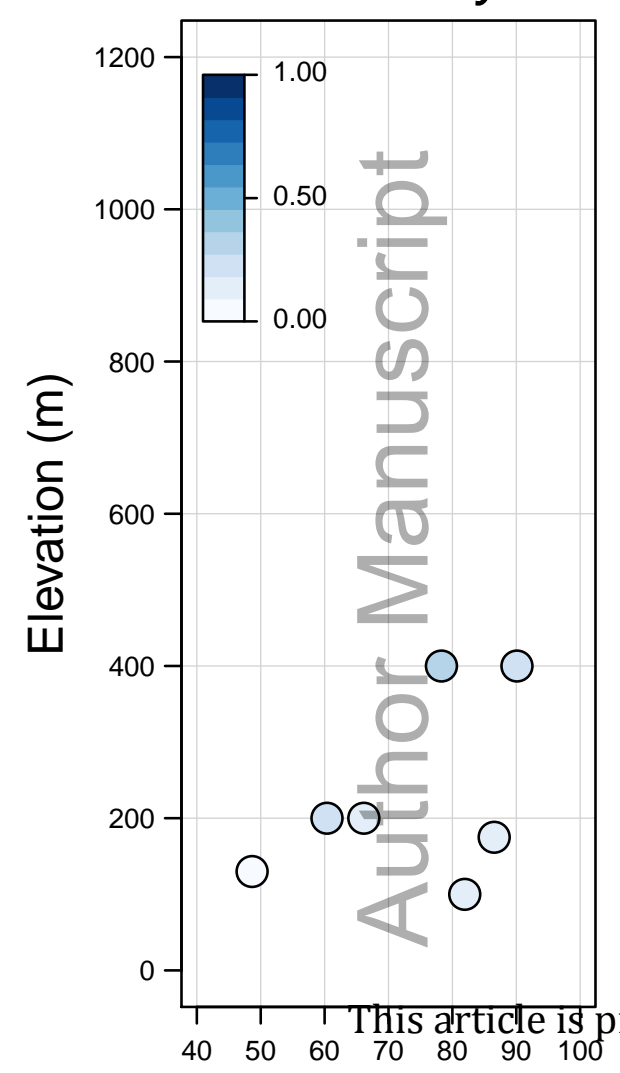

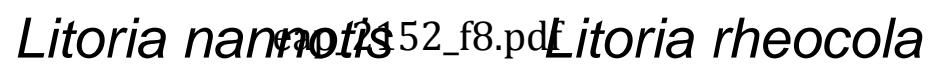

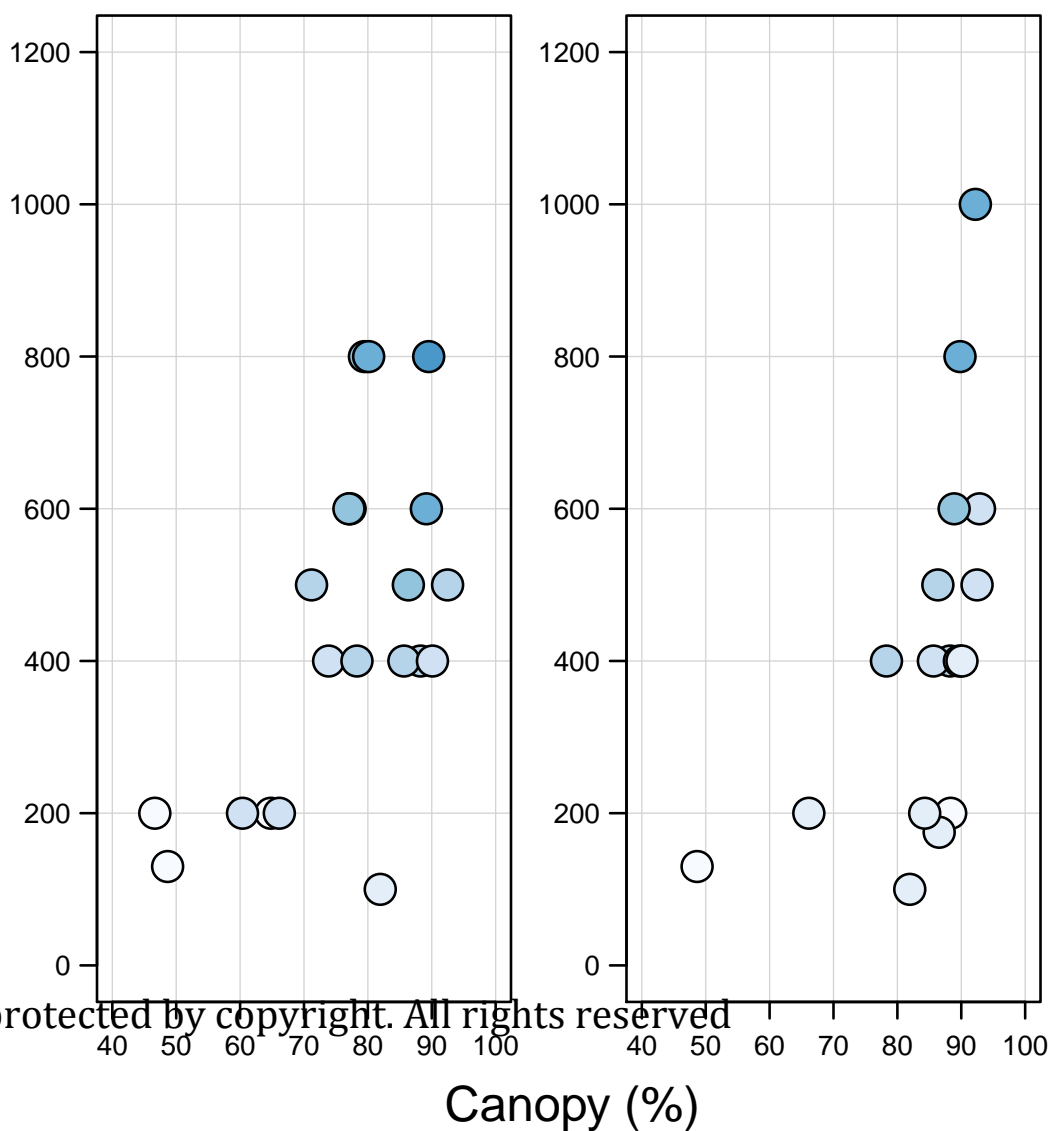

Litoria serrata

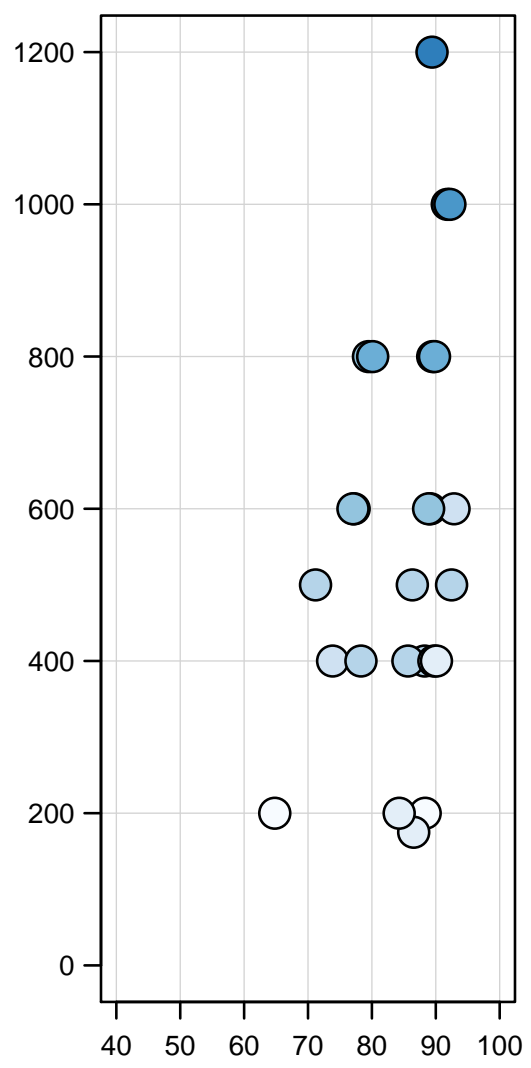




\section{University Library}

\section{- M M I N E R VA A gateway to Melbourne's research publications}

Minerva Access is the Institutional Repository of The University of Melbourne

Author/s:

Bell, SC;Heard, GW;Berger, L;Skerratt, LF

Title:

Connectivity over a disease risk gradient enables recovery of rainforest frogs

Date:

2020-06-01

Citation:

Bell, S. C., Heard, G. W., Berger, L. \& Skerratt, L. F. (2020). Connectivity over a disease risk gradient enables recovery of rainforest frogs. ECOLOGICAL APPLICATIONS, 30 (7), https:// doi.org/10.1002/eap.2152.

Persistent Link:

http://hdl.handle.net/11343/275813 